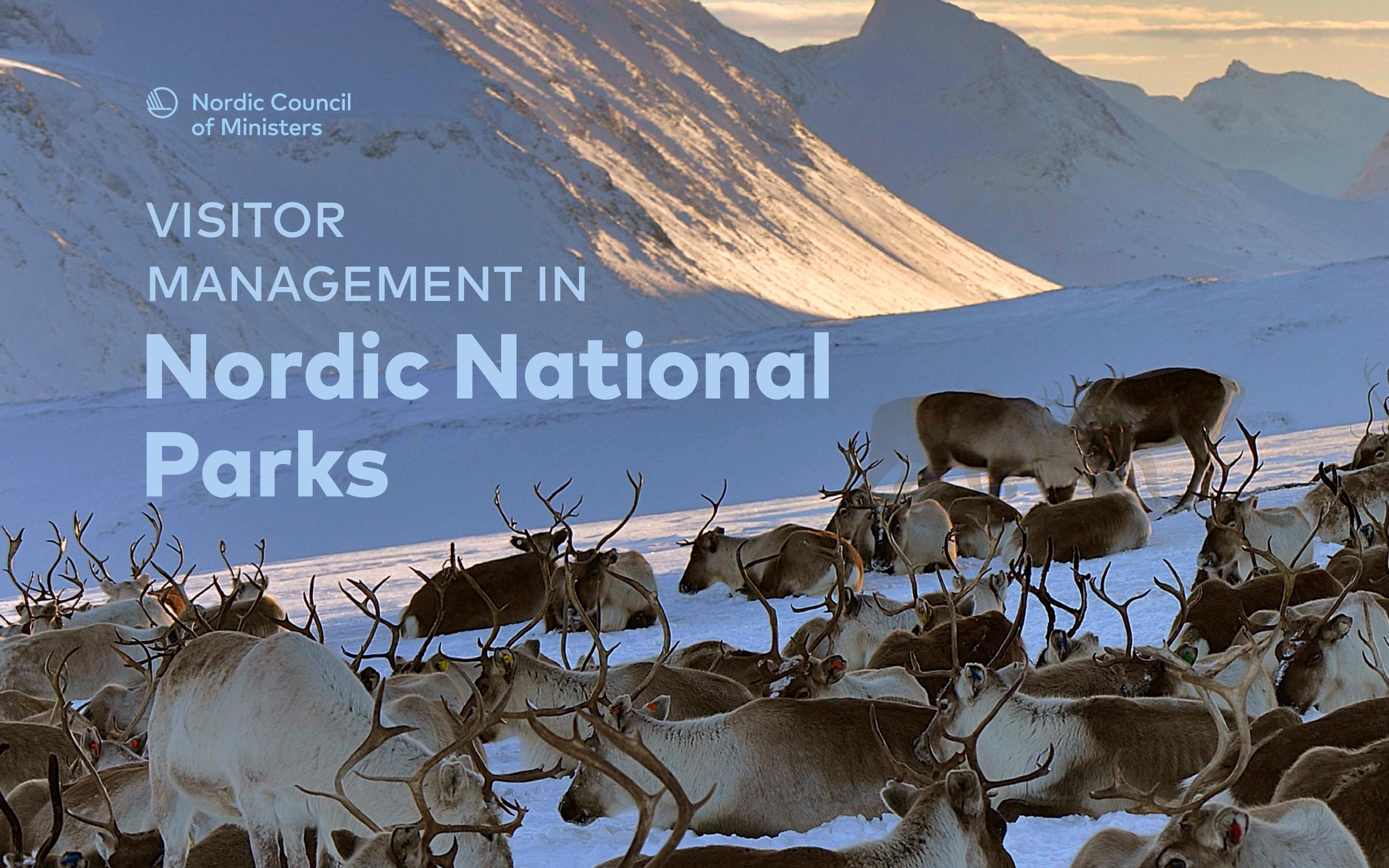


Visitor Management in Nordic National Parks

\section{Nord 2019:019}

ISBN 978-92-893-6116-3 (PDF)

ISBN 978-92-893-6117-0 (EPUB)

http://dx.doi.org/10.6027/Nord2019-019

\section{(c) Nordic Council of Ministers 2019}

\section{Layout: Le Bureau ApS}

Cover photo: Jan Stokstad, Jotunheimen National Park, Norway

\section{Nordic co-operation}

Nordic co-operation is one of the world's most extensive forms of regional

collaboration, involving Denmark, Finland, Iceland, Norway, Sweden, the Faroe Islands,

Greenland, and Åland.

Nordic co-operation has firm traditions in politics, the economy, and culture. It plays an im-portant role in European and international collaboration, and aims at creating a strong Nordic community in a strong Europe.

Nordic co-operation seeks to safeguard Nordic and regional interests and principles in the global community. Shared Nordic values help the region solidify its position as one of the world's most innovative and competitive.

\section{Nordic Council of Ministers}

Nordens Hus

Ved Stranden 18

DK-1061 Copenhagen

www.norden.org

Download Nordic publications from www.norden.org/nordpub 


\section{Contents}

Introduction

What is a Nordic national park?

Trends and challenges

10

Inspiration for visitor management solutions

Adaptive management

On-site communication

Online communication

Site-specific guidelines and codes of conduct

Quality standards

Stakeholder partnerships

Monitoring

Method 
Introduction

\author{
Visitor management is a key tool in improving \\ the recreational carrying capacity of the Nordic \\ national parks. A more strategic and collaborative \\ approach to visitor management can help protect \\ and develop the parks in a sustainable way, \\ preparing them for growing visitor numbers.
}

This publication intends to offer Nordic national park managers and national park au thorities inspiration on how to improve their visitor management. It contains examples of what other national parks, within as well as outside of the Nordic countries, have done to improve their visitor management and suggests overall recommendations on how to create better visitor management within a Nor dic framework.

The publication is the result of a project supported by The Nordic Council of Ministers' Terrestrial Ecosystem Group (TEG) and carried out in a partnership consisting of Thingvellir National Park in Iceland, Jotunheimen $\mathrm{Na}$ tional Park in Norway and The Wadden Sea National Park in Denmark, with BARK Rådgivning ${ }^{1}$ acting as project manager.

Visitor management is a key tool in improving the recreational carrying capacity of Nordic national parks, in light of the challenges presented by growing visitor numbers and new types of visitor behaviour. A more strategic and collaborative approach to visitor management can help protect and develop national parks and their local communities in both an environmentally, socially and economically sustainable way.

BARK is an independent specialist consultancy working with strategic place innovation and development in the built world.

\section{Recreational carrying capacity}

The recreational carrying capacity refers to the intensity and form of recreational use that an area can tolerate without creating a negative impact on:

$\rightarrow$ Natural and cultural heritage

$\rightarrow$ Other visitors

$\rightarrow$ The local community (socially as well as economically)

The recreational carrying capacity is not a fixed value and needs to be defined and as sessed based on the individual context of a given national park or area. The carrying capacity of a specific area can be high when it comes to nature, but low when it comes to social and local parameters, or vice versa.

An increase in visitor numbers as well as a change in visitor behaviour can create a range of carrying capacity challenges. This publication shows examples of different solution that all create or support better visitor man

WHAT IS VISITOR MANAGEMENT

This publication defines visitor management as ways to manage and affect the behaviour of visitors through various types of practical or strategic solutions. 
agement and address one or more of the carrying capacity challenges shown in the mode below. The solutions range from practical and physical solutions to strategic management solutions and are divided into seven types:

$\rightarrow$ Adaptive management

$\rightarrow$ On-site communication and guiding

$\rightarrow$ Online communication and PR

$\rightarrow$ Site-specific guidelines and codes of conduct

$\rightarrow$ Quality standards

$\rightarrow$ Stakeholder partnerships

$\rightarrow$ Monitoring

\begin{tabular}{|l|l|}
\hline $\begin{array}{l}\text { ENVIRONMENTAL CHALLENGES } \\
\text { Strain on landscape (flora, geology, } \\
\text { cultural heritage) }\end{array}$ & $\begin{array}{l}\text { SOCIAL CHALLENGES } \\
\rightarrow \text { Congestion and over-crowding of parking } \\
\text { lots, service facilities, visitor centres etc. }\end{array}$ \\
$\begin{array}{l}\rightarrow \text { Over-crowding affects unspoiled nature } \\
\text { experience }\end{array}$ \\
$\begin{array}{l}\rightarrow \text { Rescue operations / accidents } \\
\text { LOCAL CHALLENGES of wild life }\end{array} \rightarrow \begin{array}{l}\text { Behaviour related conflicts with other users } \\
\rightarrow \text { Over-crowding disturbs unspoiled } \\
\text { nature experience }\end{array}$ \\
$\begin{array}{l}\text { Locals feeling pushed out of an area, } \\
\text { which used to 'belong' to them }\end{array}$ & $\begin{array}{l}\text { ECONOMIC CHALLENGES } \\
\text { Large tour companies (cruise companies } \\
\text { and others) operate outside of local value } \\
\text { chain, not contributing to local economy } \\
\text { and growth }\end{array}$ \\
$\begin{array}{l}\text { Behaviour related conflicts between } \\
\text { locals and users }\end{array}$ & $\begin{array}{l}\text { Tourism businesses putting focus on short } \\
\text { term turnover potential, rather than long } \\
\text { term sustainability (undermining their own } \\
\text { source of revenue in the long run) }\end{array}$ \\
\hline
\end{tabular}

Improving the recreational carrying capacity through better visitor management is a com mon responsibility shared by parks, authorities, local tourism actors and local communities.

Often, the administrative and personnel resources in Nordic national parks are limited. The park administrations' task is often focused on communicating park values and experiences to locals and visitors, and on $\mathrm{fa}$ cilitating different kinds of partnerships with relevant stakeholders; while formal authority most often lies with the environmental agencies of each country. This calls for cooperation
- often successfully created through various formal and informal partnership models as shown in some of the examples in this publication.

In the Nordic countries, the public right of ac cess to nature is not only a set of legal framework conditions, but also a deeply rooted valve that affects the way visitors are managed, even in parks where the public right of access

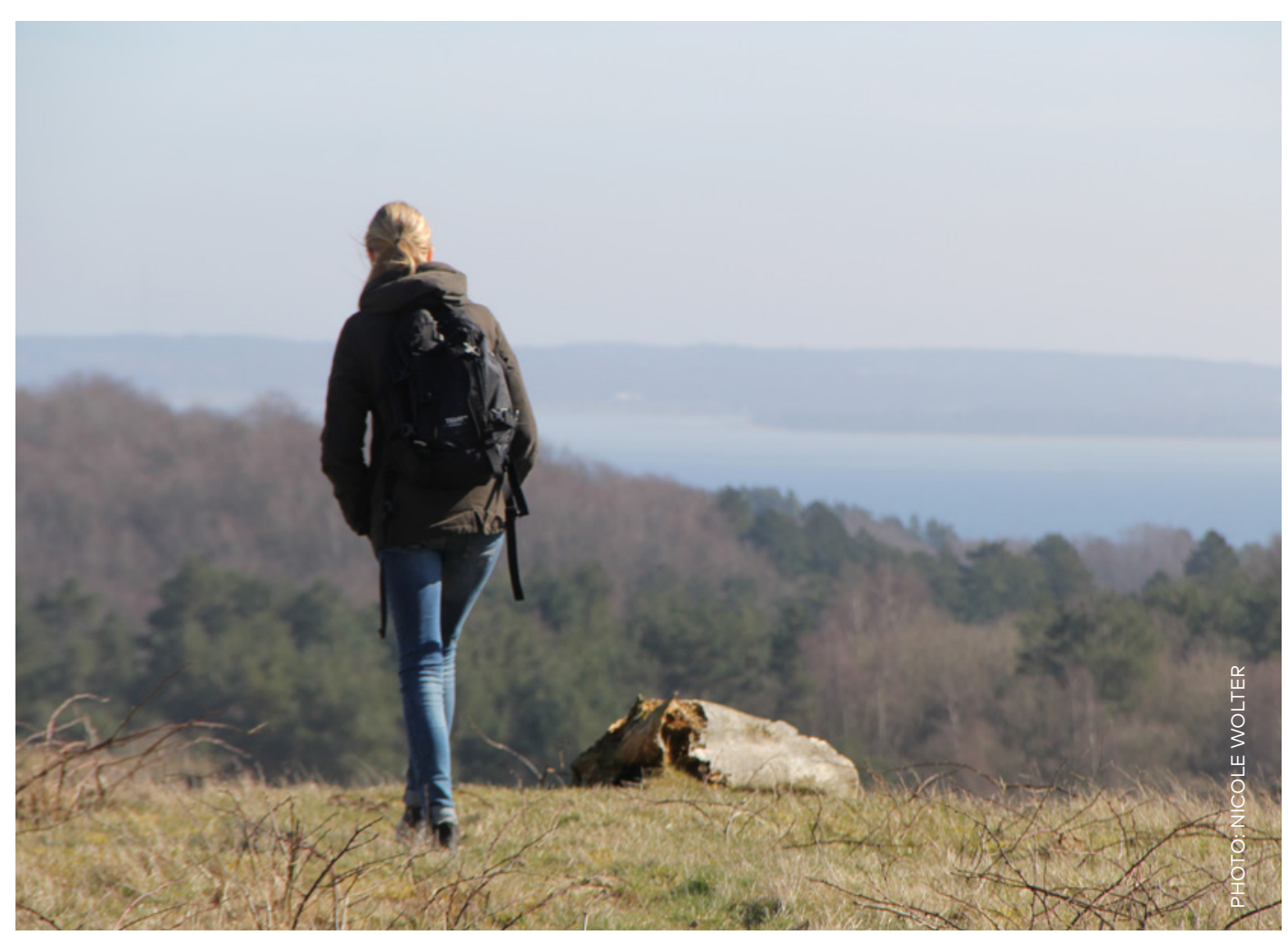

is restricted. It is a trust-based approach to erence for 'soft' visitor management tools such as information campaigns, codes of conduct, collaborative partnership models and a focus on creating local ownership and pride, rather than 'hard' tools such as fences, prohibitions, limited access, entry fees, etc.

Mols Bjerge National Park, Denmark. visitor management which entails a pref- 


\section{What is}

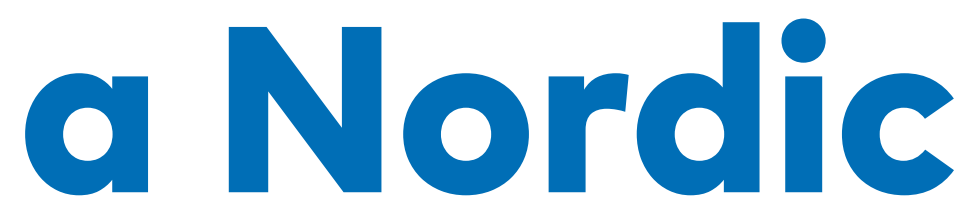

national

park?

The purpose of the Nordic national parks is to protect and conserve the natural and cultural heritage, to communicate the parks natural and cultural values and to support local development. A shared value across all Nordic parks is the concept of public right of access, creating a trust-based approach to visitor management.

\section{What is a national park?}

The International Union for Conservation of Nature (IUCN) has defined six protected area categories - from Strict Nature Reserve to Protected area with sustainable use of natural resources. National Parks belong in category II:

\section{Category Il: National Park}

Large natural or near natural areas set aside to protect large-scale ecological processes, along with the complement of species and ecosystems characteristic of the area, which also provide a foundation for environmentally and culturally compatible spiritual, scientific, educational, recreational and visitor opportunities.

(Source: www.iucn.org)

As defined by the IUCN, the primary objective of a national park is to protect natural biodiversity along with its underlying ecological structure and supporting environmental processes.

Other objectives include managing visitor use for inspirational, educational, cultural and recreational purposes and contributing to local economies through tourism.

Thus, national parks are responsible for uniting the tasks of protection and use in the interest of both nature, visitors and local community.
The Nordic national parks

Sweden was the first European country to establish a national park in 1909. Since then the number of Nordic national parks has risen steadily. The most recent one, North Zealand of the Kings National Park, was established in Denmark in 2018.

In most Nordic countries, the land of the national parks is state-owned. In Denmark, however, the land ownership is often shared by the state, municipalities, private landowners and funds. Nordic parks are largely uninhabited except those in Denmark, where you might find villages and farms.

With the exception of Denmark, the landscape in most Nordic national parks consists primarily of natural areas, such as forest ar eas, coastal areas, mountains and peatlands without agriculture. Danish national parks in clude natural areas such as coastline, dunes, heathland, as well as cultural and agricultura landscapes. In Finland, Sweden and Norway, some parks have livestock or reindeer grazing. In some Nordic national parks, traces from the historical use of a landscape constitute a valuable cultural heritage that must be protected and communicated together with the unique nature of the park.

The administration and services of the Nordic national parks are largely financed by the 
national government budgets. Establishing a national park is a governmental decision in al of the Nordic countries, with Ministry of the Environment or national agencies for the environment typically establishing the parks. The ways the parks are managed vary from country to country - see chart on the next page.

Although there is some variation among the five countries, many of the Nordic national parks now work with a bottom-up approach involving user groups, local residents, farmers, tourism organisations, local councils etc. in the strategic development of the parks. In Denmark, national park management and development is based on voluntary commitment and involvement of the local community and other key stakeholders, in part due to the ownership structure. The Danish part of The Wadden Sea is home to 11,000 individual landowners, all of whom should take an active ownership of park values and strategies.

The purposes of establishing the Nordic national parks are very similar: To protect and conserve the natural and cultural her itage, to communicate and spread awareness of the value and experiences which the park has to offer to locals and tourists and to create a breeding ground for community and business development.

Utladalen landscape protected area, Norway.
Nordic national parks are different in many ways, from nature and landscapes to land ownership. Nevertheless, a common feature across all parks and countries is the legal concept of the public right of access, national variations and local limitations aside. The idea that everybody has the right to access nature is not only a legal right, but also deeply rooted Nordic value, based on a com- mon understanding of the rights and duties that apply to the interaction with the nature that belongs to us all.

Closely related to this idea of public right of access is the idea of preserving the experience of unspoiled nature and cultural landscapes, i.e. experiences dominated by nature and landscapes in their raw, unmediated form and not by signs, service facilities, viewing towers, motorised vehicles, large events, etc.

This trust-based approach of public right of access and the idea of the unspoiled nature experience runs at the very core of visitor management in the Nordic national parks and has been challenged in recent years due to growing visitor numbers.

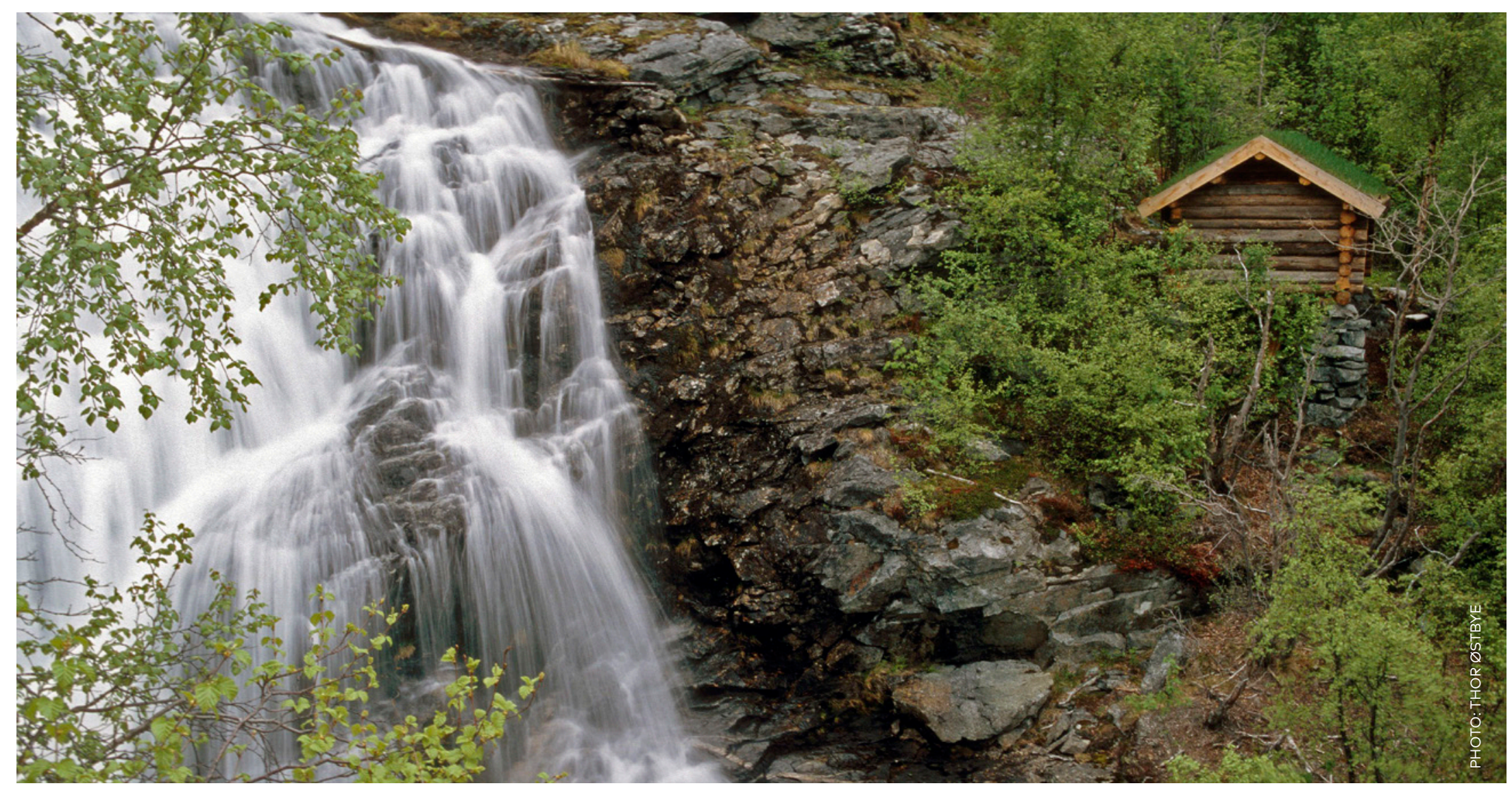




\section{Comparison chart}

\begin{tabular}{|c|c|c|c|c|c|}
\hline & Iceland & Norway & Denmark & Sweden & Finland \\
\hline Number of parks & $\rightarrow 3$ & $\rightarrow 41$ & $\rightarrow 5$ & $\rightarrow 30$ & $\rightarrow \quad 35$ \\
\hline $\begin{array}{l}\text { First national park } \\
\text { established }\end{array}$ & $\rightarrow 1930$ & $\rightarrow 1962$ & $\rightarrow \quad 2009$ & $\rightarrow 1909$ & $\rightarrow 1938$ \\
\hline $\begin{array}{l}\text { Natural and cultural } \\
\text { landscapes }\end{array}$ & $\begin{array}{l}\rightarrow \text { Primarily natural areas, } \\
\text { but also some historical, } \\
\text { cultural landscapes and } \\
\text { with a few exceptions of } \\
\text { agriculture. }\end{array}$ & $\begin{array}{l}\rightarrow \text { Primarily natural (and coast- } \\
\text { al) areas with some livestock } \\
\text { grazing. } \\
\rightarrow \text { (Protected cultural land- } \\
\text { scapes often fall in the cat- } \\
\text { egory of 'landskapsvernom- } \\
\text { råder', the least strict form } \\
\text { of area protection in Norway } \\
\text { used to protect cultural land- } \\
\text { scapes in active use). }\end{array}$ & $\begin{array}{l}\rightarrow \text { Cultural and agricultural } \\
\text { landscapes, but also natu- } \\
\text { ral areas such as coastline, } \\
\text { dunes, heaths, salt marshes } \\
\text { etc., as well as sea and fiord. }\end{array}$ & $\begin{array}{l}\rightarrow \text { Natural areas with some } \\
\text { livestock grazing. But also } \\
\text { some historical, agricultur- } \\
\text { al landscapes (e.g. reindeer } \\
\text { herding landscape, meadows } \\
\text { and pastures). }\end{array}$ & $\begin{aligned} \rightarrow & \text { Primarily natural areas with } \\
& \text { some livestock grazing. }\end{aligned}$ \\
\hline $\begin{array}{l}\text { Built structures } \\
\text { (Note: Examples of built } \\
\text { structures could be board- } \\
\text { walks, viewing platforms, } \\
\text { bridges, picnic areas, shelters } \\
\text { and campfires). }\end{array}$ & $\begin{aligned} & \rightarrow \text { Building new structures is } \\
& \text { allowed for the purpose } \\
& \text { of visitor management if } \\
& \text { compliant with manage- } \\
& \text { ment plan. } \\
& \rightarrow \text { Iceland has a fairly liberal } \\
& \text { approach when it comes } \\
& \text { to permitting new built } \\
& \text { structures in their national } \\
& \text { parks. }\end{aligned}$ & $\begin{aligned} \rightarrow & \text { Building new structures are } \\
& \text { allowed for the purpose of } \\
& \text { visitor management if compli- } \\
& \text { ant with management plan. } \\
\rightarrow & \text { Norway has a fairly strict } \\
& \text { approach when it comes to } \\
& \text { permitting new built struc- } \\
& \text { tures in their national parks. } \\
\rightarrow & \text { The parks have traces from } \\
& \text { the historical use of the area } \\
& \text { and landscape: mountain } \\
& \text { farms, hunting and fishing } \\
& \text { cabins, samii rein herding etc. } \\
\rightarrow & \text { Nearly all motorized vehicles } \\
& \text { are prohibited, and the parks } \\
& \text { have no modern infrastruc- } \\
& \text { ture for these by definition. }\end{aligned}$ & $\begin{aligned} & \rightarrow \text { Built structures are a pre-ex- } \\
& \text { isting, functioning part of all } \\
& \text { Danish national parks. } \\
& \rightarrow \text { Denmark has a fairly liberal } \\
& \text { approach when it comes to } \\
& \text { permitting new built struc- } \\
& \text { tures in their national parks } \\
& \text { compared to e.g. Norway. The } \\
& \text { national park administrations } \\
& \text { follow the general legislation } \\
& \text { in this aspect, especially The } \\
& \text { Nature Protection Act. } \\
& \rightarrow \text { When establishing a national } \\
& \text { park, rules can be established } \\
& \text { for the municipal planning } \\
& \text { within the area. }\end{aligned}$ & $\begin{array}{l}\rightarrow \text { Building new structures are } \\
\text { allowed for the purpose of } \\
\text { visitor management if compli- } \\
\text { ant with management plan. }\end{array}$ & $\begin{aligned} & \rightarrow \text { Building new structures are al- } \\
& \text { lowed for the purpose of visitor } \\
& \text { management if compliant with } \\
& \text { management plan. }\end{aligned}$ \\
\hline Residents & $\begin{aligned} \rightarrow & \text { No residents, except a few } \\
& \text { residents in Vatnajökull and } \\
& \text { Thingvellir National Parks. }\end{aligned}$ & $\rightarrow$ No residents. & $\begin{array}{l}\rightarrow \begin{array}{l}\text { Residents in all national } \\
\text { parks. }\end{array}\end{array}$ & $\rightarrow$ No residents. & $\begin{array}{l}\rightarrow \text { No residents on state-owned } \\
\text { land, but in a few places people } \\
\text { are living on privately-owned } \\
\text { land within the national park. }\end{array}$ \\
\hline
\end{tabular}




\begin{tabular}{|c|c|c|c|c|c|}
\hline & Iceland & Norway & Denmark & Sweden & Finland \\
\hline Land ownership & $\begin{array}{l}\rightarrow \text { Primarily state-owned land } \\
\text { (Vatnajökull National Park } \\
\text { contains some private- } \\
\text { ly-owned land). The state- } \\
\text { owned land is under the } \\
\text { administration of Ministry } \\
\text { for the Environment and } \\
\text { Natural Resources. }\end{array}$ & $\begin{array}{l}\rightarrow \text { Primarily state-owned land. } \\
\rightarrow \text { Statskog SF is a public enter- } \\
\text { prise responsible for national } \\
\text { land, but with little responsi- } \\
\text { bility for management/ devel- } \\
\text { opment of protected areas on } \\
\text { its land. Statskog SF belongs } \\
\text { to the Ministry of Agriculture } \\
\text { and Food. }\end{array}$ & $\begin{array}{l}\rightarrow \text { A mix of land owned by the } \\
\text { state, private individuals, } \\
\text { municipalities and funds. The } \\
\text { state-owned land is under the } \\
\text { administration of The Danish } \\
\text { Nature Agency. }\end{array}$ & $\begin{array}{l}\rightarrow \text { State-owned land under the } \\
\text { administration of the Swed- } \\
\text { ish Environmental Protection } \\
\text { Agency. }\end{array}$ & $\begin{array}{l}\rightarrow \text { State-owned land under the ad- } \\
\text { ministration of the state-owned } \\
\text { organization Metsähallitus. }\end{array}$ \\
\hline Organisation & $\begin{aligned} & \rightarrow \text { Establishing a national } \\
& \text { park is a governmental } \\
& \text { decision. } \\
& \rightarrow \text { In Iceland there are three } \\
& \text { national parks which are } \\
& \text { run by three different } \\
& \text { organisations, all under the } \\
& \text { Ministry for the Environ- } \\
& \text { ment and Natural Resourc- } \\
& \text { es. } \\
& \rightarrow \text { Thingvellir National Park is } \\
& \text { under the administration } \\
& \text { of Thingvallanefnd Com- } \\
& \text { mittee. } \\
& \rightarrow \text { Snæfellsjökull National } \\
& \text { Park is under the adminis- } \\
& \text { tration of The Environment } \\
& \text { Agency of Iceland. } \\
& \rightarrow \text { Vatnajökull National Park } \\
& \text { is under the administration } \\
& \text { of a board, set up by the } \\
& \text { Minister for the Environ- } \\
& \text { ment and Natural Resourc- } \\
& \text { es. } \\
& \rightarrow \text { Thingvellir National Park } \\
& \text { and Vatnajökull National } \\
& \text { Park are under two diffe- } \\
& \text { rent administrations and } \\
& \text { led by two different park } \\
& \text { managers. Snæfelljökull } \\
& \text { National Park has an advi- } \\
& \text { sory committee and is run } \\
& \text { by a park manager. }\end{aligned}$ & $\begin{aligned} \rightarrow & \text { Establishing a national park is } \\
& \text { a governmental decision. } \\
\rightarrow & \text { The Norwegian Environment } \\
& \text { Agency is responsible for the } \\
& \text { establishment and manage- } \\
& \text { ment of the national parks. } \\
\rightarrow & \text { The agency sets up a nation- } \\
& \text { al park board with local and } \\
& \text { regional political representa- } \\
& \text { tives. } \\
\rightarrow & \text { Each national park is run by } \\
& \text { an administration led by one } \\
& \text { or two national park man- } \\
& \text { agers that also function as } \\
& \text { secretary for the board. } \\
\rightarrow & \text { The national park managers } \\
& \text { are employed by the County } \\
& \text { Govenor (Fylkesmannen). }\end{aligned}$ & $\begin{aligned} \rightarrow & \text { Establishing a national park is } \\
& \text { a governmental decision. } \\
\rightarrow & \text { The Danish Environmental } \\
& \text { Protection Agency is respon- } \\
& \text { sible for the establishment of } \\
& \text { the national parks. } \\
\rightarrow & \text { The national parks are inde- } \\
& \text { pendent funds which receive } \\
& \text { government funding. The } \\
& \text { agency sets up a national } \\
\text { park board with represent- } & \text { atives from municipalities, } \\
& \text { state, NGOs and the local } \\
& \text { national park council. } \\
\rightarrow & \text { The national park boards are } \\
& \text { responsible for the manage- } \\
& \text { ment of the parks. } \\
\rightarrow & \text { Each national park is run by } \\
& \text { an administration led by a } \\
& \text { national park manager. }\end{aligned}$ & $\begin{aligned} & \rightarrow \text { Establishing a national park is } \\
& \text { a governmental decision. } \\
& \rightarrow \text { The Swedish Environmental } \\
& \text { Protection Agency is respon- } \\
& \text { sible for the establishment of } \\
& \text { the national parks in cooper- } \\
& \text { ation with municipalities and } \\
& \text { county. } \\
& \rightarrow \text { Each national park is man- } \\
& \text { aged by the county adminis- } \\
& \text { tration board in the county } \\
& \text { where the national park is } \\
& \text { situated, but in some cases, } \\
& \text { the government can appoint } \\
& \text { another party to be the man- } \\
& \text { ager. }\end{aligned}$ & $\begin{aligned} & \rightarrow \text { Establishing a national park is a } \\
& \text { governmental decision. } \\
& \rightarrow \text { The Ministry of Environment is } \\
& \text { responsible for the establish- } \\
& \text { ment of new national parks, } \\
& \text { but the expertise of the state- } \\
& \text { owned organization Metsähal- } \\
& \text { litus is used as a helping hand } \\
& \text { in public hearings, design of } \\
& \text { boundaries and formulation of } \\
& \text { legal statutes. } \\
& \rightarrow \text { Parks \& Wildlife Finland, a divi- } \\
& \text { sion under Metsähallitus, is in } \\
& \text { charge of managing the national } \\
& \text { parks. This means that the Finn- } \\
& \text { ish national parks are not run by } \\
& \text { a park manager appointed by a } \\
& \text { board, as opposed to the other } \\
& \text { Nordic national parks. }\end{aligned}$ \\
\hline
\end{tabular}




\section{Trends and challenges}

Nature-based tourism is growing fast, also in the Nordic countries, increasingly turning popular sites in Nordic national parks into global mass-tourism destinations and creating problems like over-crowding, pressure on nature and conflicts in the local community. Action is needed to preserve the value and attraction of these unique destinations, as more and new types of visitors will continue to come.
Nature-based tourism is growing in the Nordic countries

Factors such as urbanisation and economi growth have made it desirable and possible for people to spend more time and money travelling. In the last 20 years, the number of international departures across the globe has increased from 600 million to 1.3 billion². Es pecially the growing urban middle classes in China and India are expected to contribute to a significant further expansion of tourism in the near future ${ }^{3}$.

Nature-based tourism is a growing industry in ts own right, and the Nordic countries have recently experienced a rapid growth in this area. In a world of political and climatic instability, cold is fast becoming the new hot, and the Nordic countries are politically stable and safe destinations offering a new kind of exotic nature.

As a result, popular 'hot spots' have changed from regional and national sites to global destinations in some Nordic national parks ${ }^{4}$. This new-found popularity results in problems such as over-crowding ${ }^{5}$, pressure on nature and cul-

Forbes.com, article by Alexandra Talty, Dec. 28th, 2017.

3 Øian et al., 'Tourism, nature and sustainability', Nordic Council of Ministers 2018, p. 18. (See full list of authors in the method section page 43).

Cian et al, 'Tourism, nature and sustainability' Nordic Council of Ministers 2018, p. 15.

5 Here, over-crowding is defined as a situation where the number of visitors in one spot at the same time causes a social carrying capacity problem, e.g. When visitors or tural heritage, accidents, costly rescue operations, an overload on public infrastructure and conflicts of interests between different visitor groups and between visitors and local citizens.

The size and nature of the problems vary from country to country, and especially some parks in Iceland and Norway are experiencing great challenges related to over-crowding caused by a sudden increase in the number of visitors to certain iconic national park attractions. This is the case for Thingvellir National Park in Iceland and The Besseggen Ridge attraction in Jotunheimen National Park in Norway.

MAIN CHALLENGES IN NORDIC NATIONAL PARKS THAT BETTER VISITOR MANAGEMENT CAN HELP ADDRESS

$\rightarrow$ Growing visitor numbers create pressure on environmental, social and local resources.

$\rightarrow$ More visitors seem to have low preexisting knowledge of how to behave in nature.

$\rightarrow$ The public right of access is not designed to handle the massive increase in visitor numbers.

$\rightarrow$ New forms of self-organized user activities and social media communication channels. 


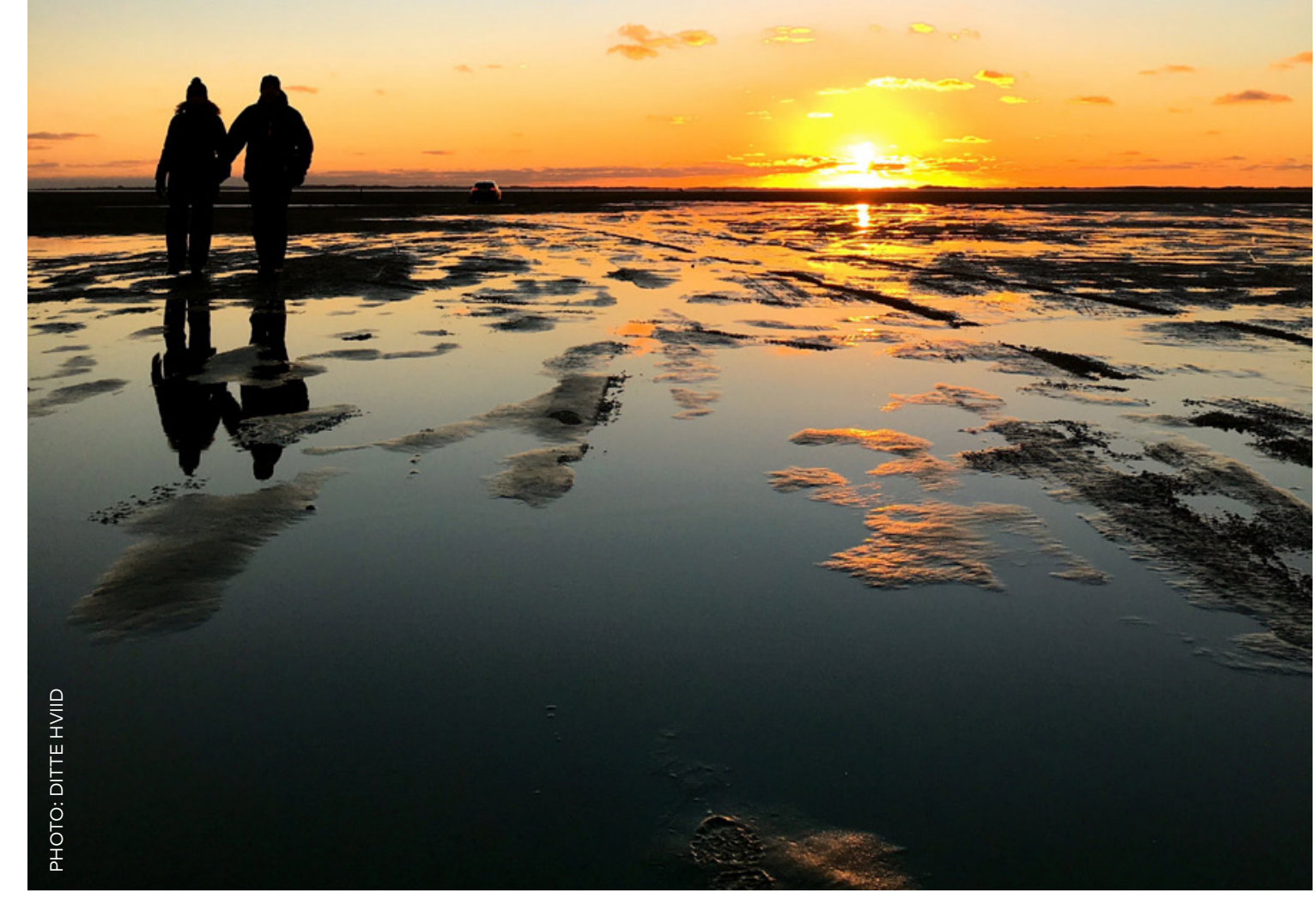

THE UNWTO TOURISM HIGHLIGHTS 2018 EDITION PRESENTS THE

FOLLOWING TOURISM NUMBERS*:

$\rightarrow 2017$ saw the highest growth in international tourist arrivals in seven years: A 7 percent increase to 1,326 million total international tourist arrivals.

$\rightarrow$ Northern Europe is up 5 percent on international tourist arrivals and 8 percent on international tourist receipts.

$\rightarrow$ In the Nordic countries, Finland and Iceland have experienced the highest growth in international tourist arrivals -14.0 and 24.1 percent, respectively. For Norway and Sweden, the numbers are 4.9 and 4.7 percent, respectively.

*World Tourism Organization (2018), UNWTO Tourism Highlights, 2018 Edition, UNWTO, Madrid.

In Finland, Denmark and Sweden, the growth in nature-based tourism has been more balanced, albeit still notable ${ }^{6}$

The increase in visitor numbers and the problems caused by this present an overall challenge to the recreational carrying capaci-

Øian et al., 'Tourism, nature and sustainability', Nordic Council of Ministers 2018, p. 20.
NATURE-BASED TOURISM IS GROWING

$\rightarrow$ In 2016, 1.2 million people visited Thingvellir National Park in Iceland.

$\rightarrow$ During 2016, 356,000 Chinese tourists arrived in Finland. This represents an increase of 35 percent compared to 2015.

$\rightarrow$ In the last five years, Trolltunga, a spectacular scenic cliff just outside the Hardangervidda National Park in Norway, has gone from 1,000 to 100,000 annual visitors.

ty and sustainability of the Nordic national parks, from both an environmental, social, local and economic perspective. Strategic action is needed to preserve the value and attraction of these unique destinations, as more and new types of visitors will continue to come.

The challenge for the Nordic national parks is to prepare for more and new types of visitors and doing so without making short-term adaptations that might in turn devaluate the unique, wild nature and landscape that visitors come to experience.

The Wadden Sea National Park, Denmark. 


\section{New visitors have low pre-existing knowledge of nature}

The demand for a greater variety of nature-based tourism experiences has seen a general growth internationally. New forms of more strenuous or 'hard' adventure activities (e.g. heli-skiing, climbing and endurance hiking) are emerging. The trend is small compared to the vast number of tourists requesting less adventurous activities. Since many of the hard adventure activities are new, take place in new areas of the national parks and involve new kinds of equipment, it is difficult to predict the long-term effects of these activities.

The majority of the growing number of tourists in Nordic national parks wants to partici pate in more 'soft', recreational activities (e.g. short hikes, canoeing and cycling). This demand is driven especially by the urban middle class, relatively wealthy senior citizens, tourists from $\mathrm{Asia}^{7}$ and the increasing share of $\mathrm{fe}$ male tourists.

The sheer number of new visitors in Nordic national parks is a challenge in itself. On top of that, the majority of these visitors are also perceived by many national park managers and employees to have a very low pre-exist-

7 This varies from country to country, but especially Iceland and Finland have seen a significant growth in Chinese tourists over the last couple of years.

8 Øian et al., 'Tourism, nature and sustainability', Nordic Council of Ministers 2018, p. 18.

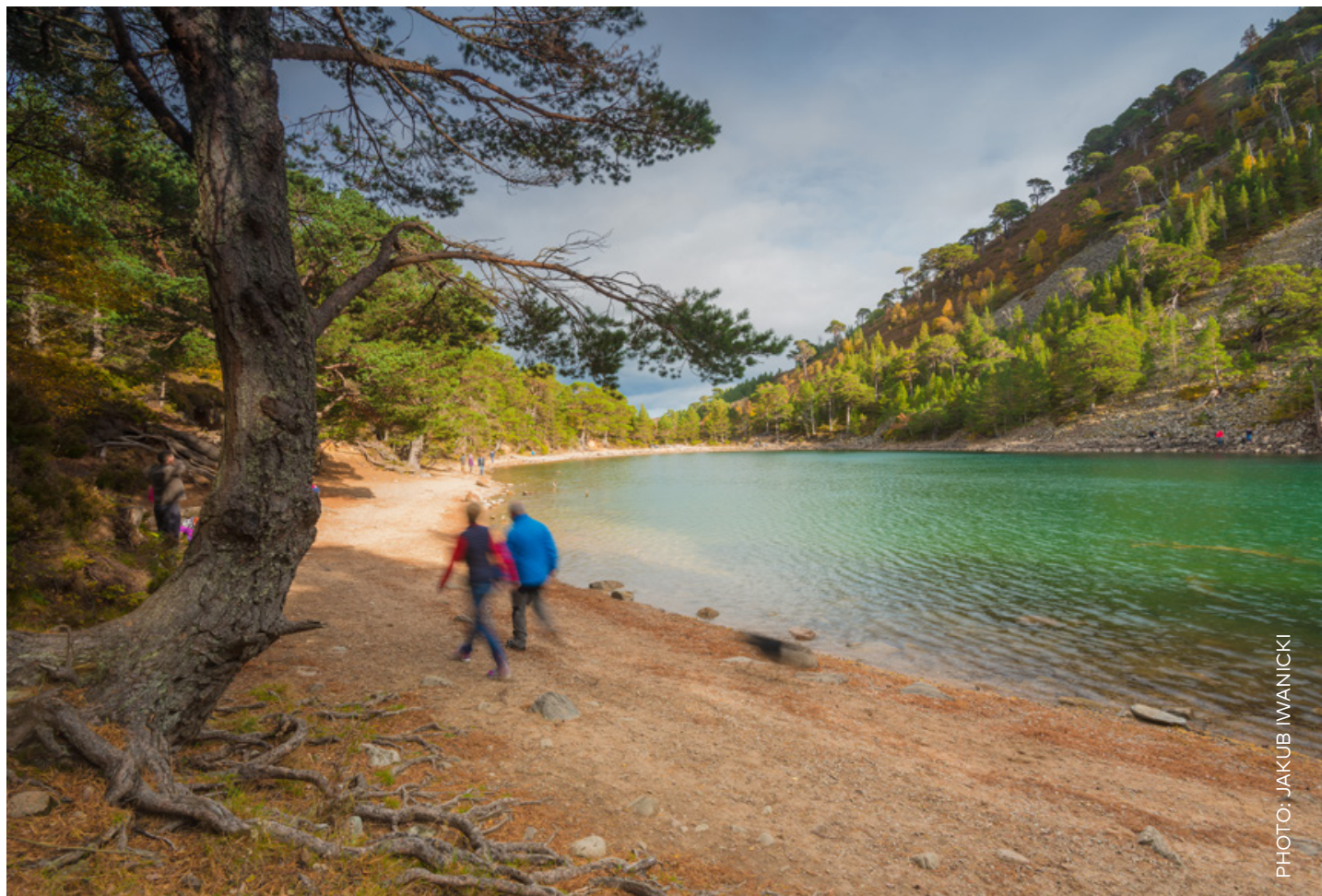

Cairngorms National Park Great Britain.

The public right of access is not designed for massive increase in visitors

As described in the previous section, the public right of access is not only a set of legal framework conditions but also an inherent value in the Nordic national parks, even though it takes a slightly different form across the five countries and can be bent to varying degrees in order to put nature protection first when needed.

The challenge surrounding the public right of access lies in the fact that it was never designed for the 'mass invasion' that some parks and sites experience today, nor for dealing ing knowledge of how to behave in nature. Almost all national park managers interviewed for this project have mentioned this as a challenge. The general view is that many visitors are unfamiliar with the specific natu ral environments and have insufficient abilities in terms of skills, experience and fitness - abilities that are often overestimated when faced with the low-service, low-facilitated nature experiences of Nordic national parks. The challenge is how to equip these visitors with a more adequate knowledge, working from the premise that they do not actively seek knowledge about the site they visit in advance, that they only stay for a short time, that they will often overestimate own abilities to get the unique nature experience they came for and that they tend to be less prone to follow rules when on vacation?

Øian et al., 'Tourism, nature and sustainability',
Nordic Council of Ministers 2018, p. 60 . with visitors without the adequate knowledge of how to balance the individual rights and duties that follow from the public right of access ${ }^{10}$. As a Nordic national park working from a premise of trust-based values rather than hard restrictions, this challenge underlines the importance of improved and specially designed visitor management strategies in a Nordic setting.

\footnotetext{
${ }^{10}$ Øian et al., 'Tourism, nature and sustainability', Nordic Council of Ministers 2018, p. 67.
} 


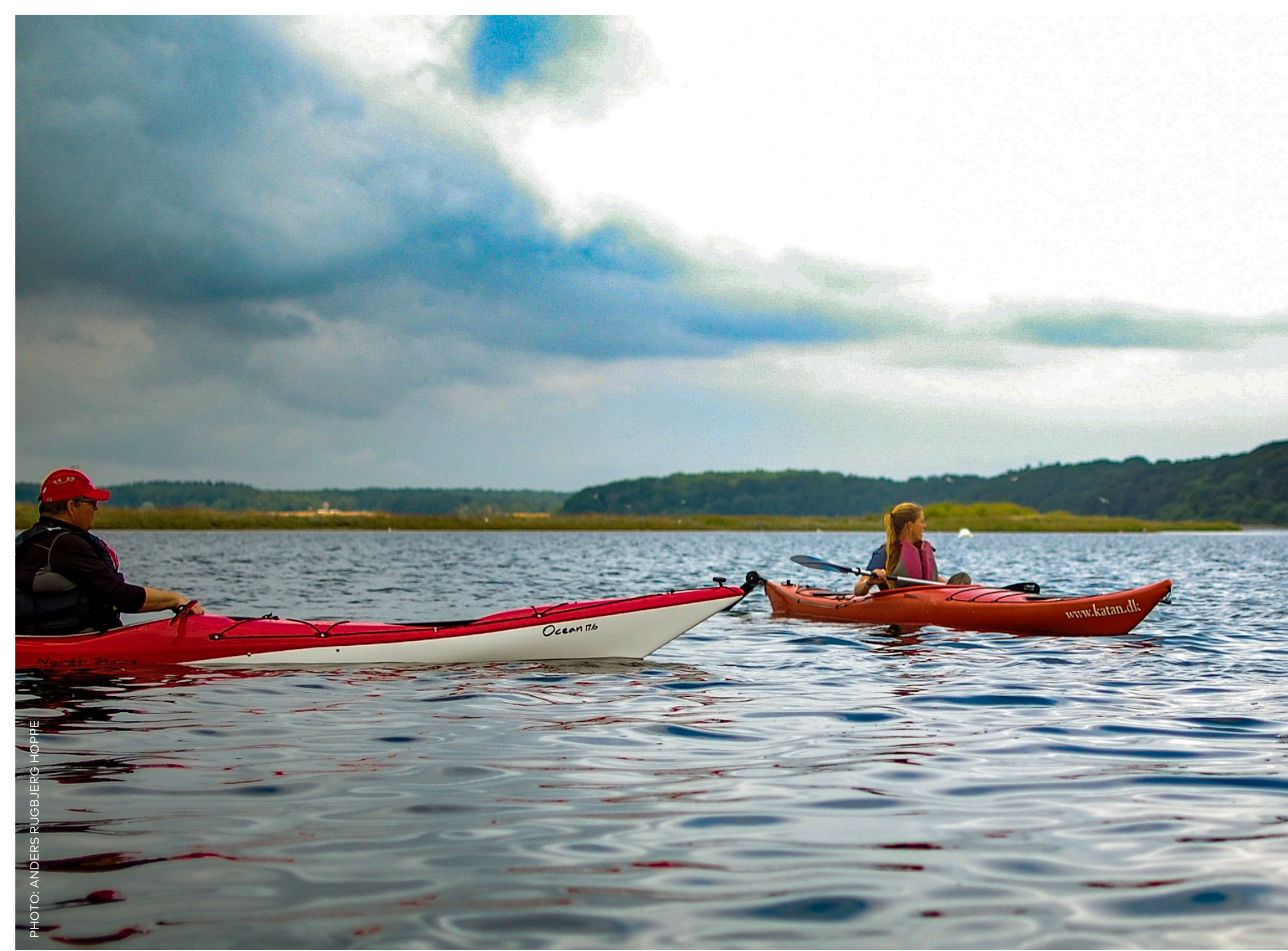

Social media is driving new, individualised visitor behaviour

Social media platforms such as Facebook and Instagram are driving a new and more individvalised tourist behaviour where information is shared, and destinations are promoted in a way that is beyond park management control. These platforms provide visitors with an easy access to information and recommendations that might not be in line with what the national park wants to promote. In this respect, social media platforms can become an uncontrolled communication channel, which promotes places in the park that are not ideal for handling large numbers of guests. Taking some degree of control over these communication channels, using them as an active tool in promoting park values, spreading visitors to less crowded places in the park, advertising new facilities, etc. are could be some of the ways of addressing this challenge.

Skjoldungernes Land National Park, Denmark. 


\section{Inspiration for visitor management solutions}

\section{Hard and soft visitor management in} a Nordic setting

When working with visitor management in a national park in a situation where growing visitor numbers have become a challenge, a range of hard and soft measures can be applied to address the situation ${ }^{11}$

Hard visitor management approaches involve using formal rules and restrictions on the physical access to the park, e.g. by using gates or payment schemes or by making physical adaptions in the park landscape such as putting up fences or hardening trails. The hard visitor management approaches are often problematic in a Nordic setting due to both legal and value-based traditions and conditions,

as mentioned elsewhere in this publication and the way these approaches alter the landscape may also reduce visitor satisfaction.

Soft visitor management approaches seek to modify the visitors' behaviour through direct or indirect education programmes, guiding,

Øian et al. Tourism, nature and sustainability,

Nordic Council of Ministers 2018 // Mason, 2005 Marion and Reid, 2007 
on-site or online information about codes of conduct, advice on clothing, suggestions for hiking routes or activities, etc. The soft ap proaches will typically not only tell visitors how not to behave, but also explain to them why a certain behaviour is (un)desirable.

Often, the soft approaches better comply with the legal and value-based framework of the Nordic national parks and have a minimal physical impact on the landscape and the respect for the legal and value-based concept of public right of access. The challenge is that the vast majority of visitors to Nordic nationa parks today have low pre-existing knowledge about how to behave in nature - a trend that will most likely continue to grow, due to urbanisation. This group of low-knowledge visitors is somewhat difficult to reach through soft management approaches only, as pointed out in a study on visitor behaviour in Antarctica and Great Barrier Reef, respectively:

"In a study conducted in Antarctica, a destination difficult to monitor, the main visitor management strategies were to transfer responsibility to visitors by informing about the serious consequences of harmful behav iour (Mason, 2005). While this kind of interpretive activity had positive impacts on the visitors' behaviour in Antarctica, the results turned out to be mixed in the Great Barrier Reef in Australia. Coghlan (2012) holds that compared to Antarctica tourists, visitors to the Great Barrier Reef in average have rela- tively little pre-knowledge about the nature resources and are less concerned about the effects of their visits on the environmental conditions of nature resources." Øian et al., 'Tourism, nature and sustainability', Nordic Council of Ministers 2018.

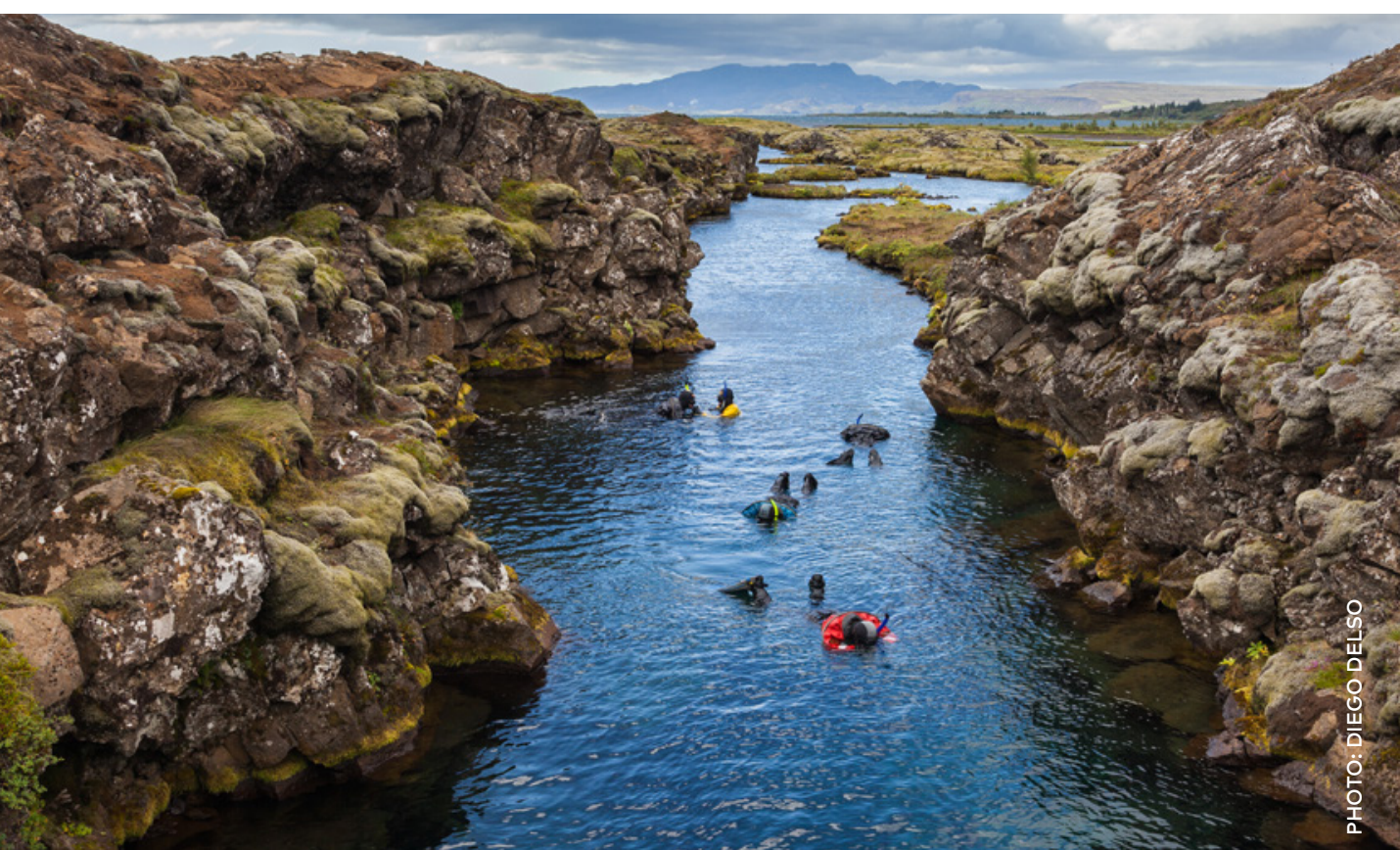

Or, as an employee from a Danish national park puts it:

"We are excellent at handling the visitors that already know a little bit about nature, because they can take care of themselves and know how to behave".

Interview, project manager, Danish national park.

\section{Adaptive management as a third} approach

A third approach lies between the hard and the soft approach, i.e. adaptive management

Thingvellir National Park Thingvellir

strategies ${ }^{12}$. Adaptive management can be used as an instrument for 'nudging' visitors to behave in a certain way. Typical adaptive management solutions in national parks in clude the zoning of activities and the stra-

2 Øian et al., 'Tourism, nature and sustainability', Nordic Council of Ministers 2018. tegic placement of facilities as means of channelling visitor traffic. The goal is to either spread, modify or concentrate visitor traffic and activities in order to improve recreational opportunities, reduce the risk of conflicts between different user groups and stakeholders and minimise the negative environmental impact on nature and cultural heritage in the park $^{13}$.

A combination of soft visitor management approaches and adaptive management should guide the development of visitor management strategies and solutions in Nordic national parks.

\section{Getting stakeholders on board is key} to visitor management success

Developing effective, sustainable visitor management strategies and solutions requires the involvement of a range of stakeholders, visitors, user group representatives, local citizens, tourism businesses, local authorities, etc.

Broad stakeholder involvement through co-creation processes and partnerships is a way to create a valuable ownership of the strategy and its implementation, mak ing sure that all stakeholders are heard and understand their role and responsibility.

đian et al., 'Tourism, nature and sustainability', Nordic Council of Ministers 2018. 


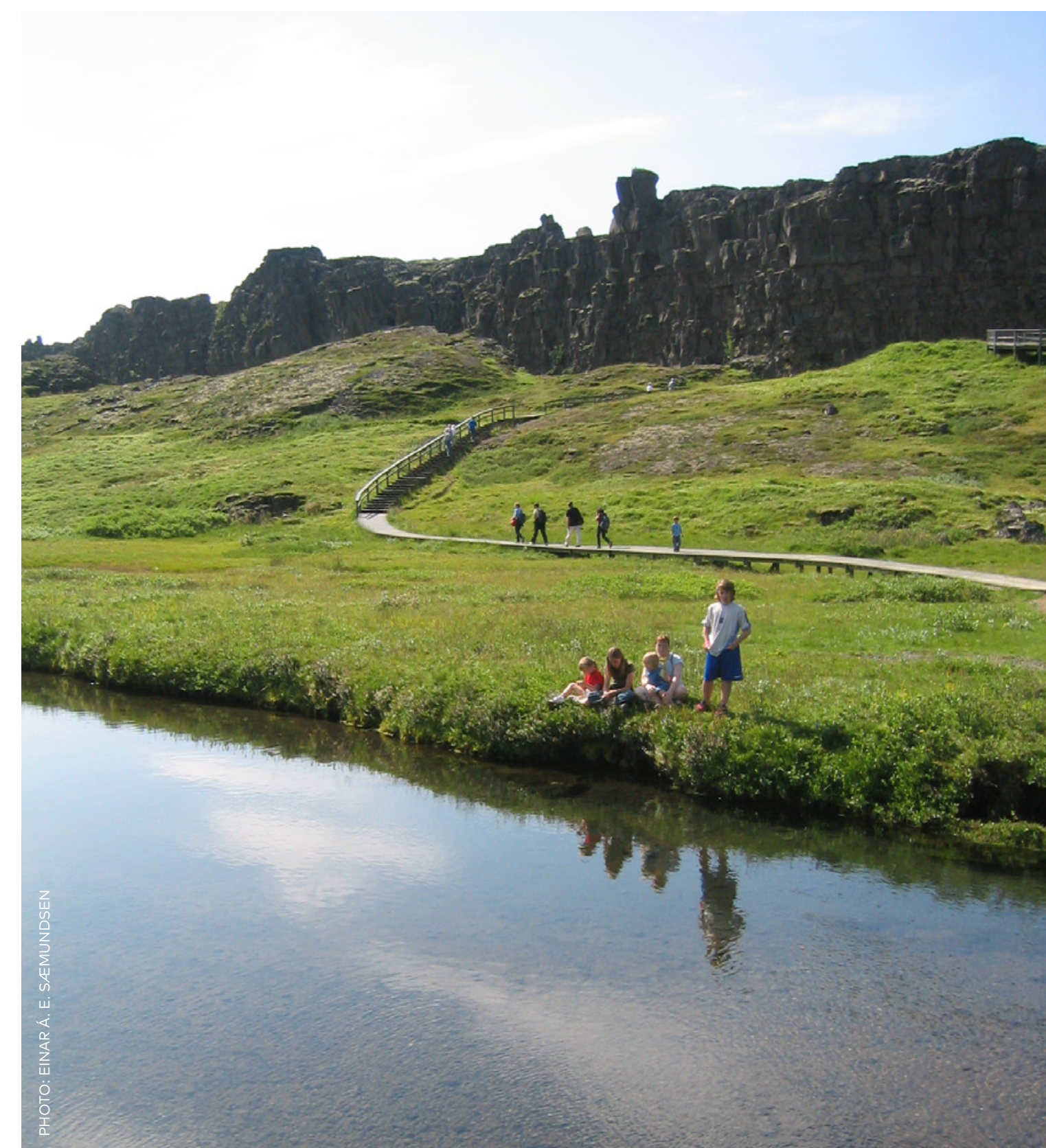

Inviting stakeholders to take an active part in the development and realisation of visito management goals is also necessary in the sense that Nordic national park administrations rely on strong, local networks in order to fulfil their overall purpose of protecting and communicating the natural and cultural valves of the parks.

These strategies should always be based on a thorough knowledge of the visitors and use the monitoring of visitor behaviour, experienc es and needs as an essential, basic tool for enabling the development of good visitor management solutions.

Often, the end result of a common development process is a partnership plan, a management plan, a code of conduct, etc. It is, however, important to notice that the process is just as important as the end product when it comes to building and maintaining a common understanding and commitment. This also explains why these processes need to be repeated on a recurring basis.

\section{Seven types of solutions for a better} visitor management

This chapter presents a range of examples of different visitor management solutions that all address one or more of the carrying ca- pacity challenges pointed out earlier in this publication.

The examples range from practical, physical solutions to more strategic management solutions and are divided into seven types. The first three solution types deal with examples of concrete tools and channels for changing visitor behaviour. The last four types show examples on how to establish a strategic framework for changing visitor behaviour:

\section{SEVEN TYPES OF SOLUTIONS:}

Concrete tools and channels for changing visitor behaviour

$\rightarrow$ Adaptive management

$\rightarrow$ On-site communication and guiding

$\rightarrow$ Online communication

Laying the foundation for changing visitor behaviour

$\rightarrow$ Site-specific guidelines and codes of conduct

$\rightarrow$ Quality standards

$\rightarrow$ Stakeholder partnerships

$\rightarrow$ Monitoring 


\section{Channelling visitor traffic through path maintenance priorities in}

\section{CAIRNGORMS NATIONAL PARK}

Cairngorms National Park in Great Britain is inhabited by a rare capercaillie bird. This species is protected by the EU legislation, and 80 percent of the capercaillie population of Great Britain lives in Cairngorms National Park. Hence, protecting the bird from being disturbed by visitors is a high priority for the park. Instead of using hard management tools such as putting up fences, the park administration focuses on channelling visitors to places in the park where they do not disturb the birds. This is done by strategically choosing which paths to maintain and which not to maintain.

In cooperation with a group of relevant stakeholders, a network of core paths has been identified. Funding will be allocated to prioritise maintenance of these paths, making them more attractive to use with the purpose of concentrating visitor traffic to certain parts of the park and leaving other areas undisturbed.

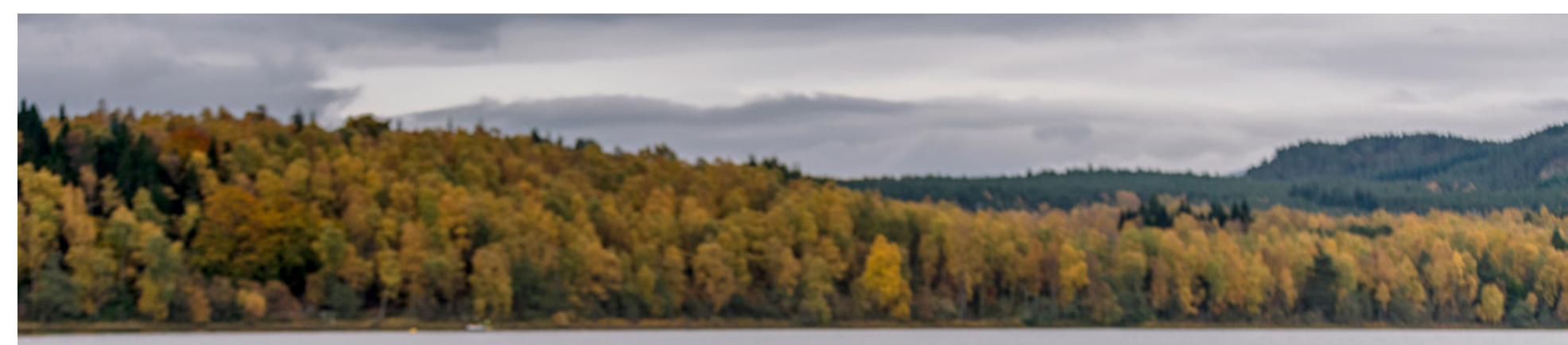

Cairngorms National Park Great Britain.

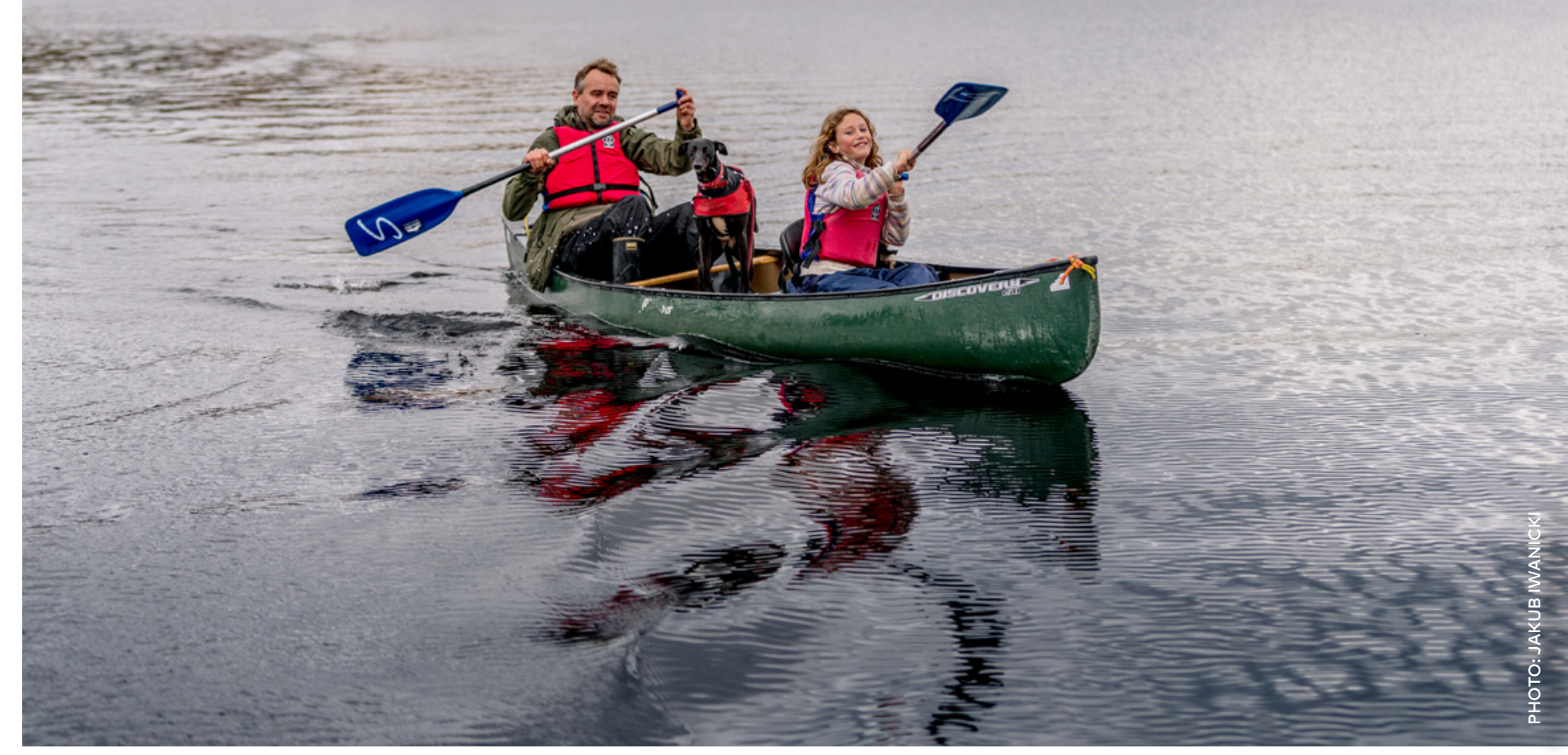




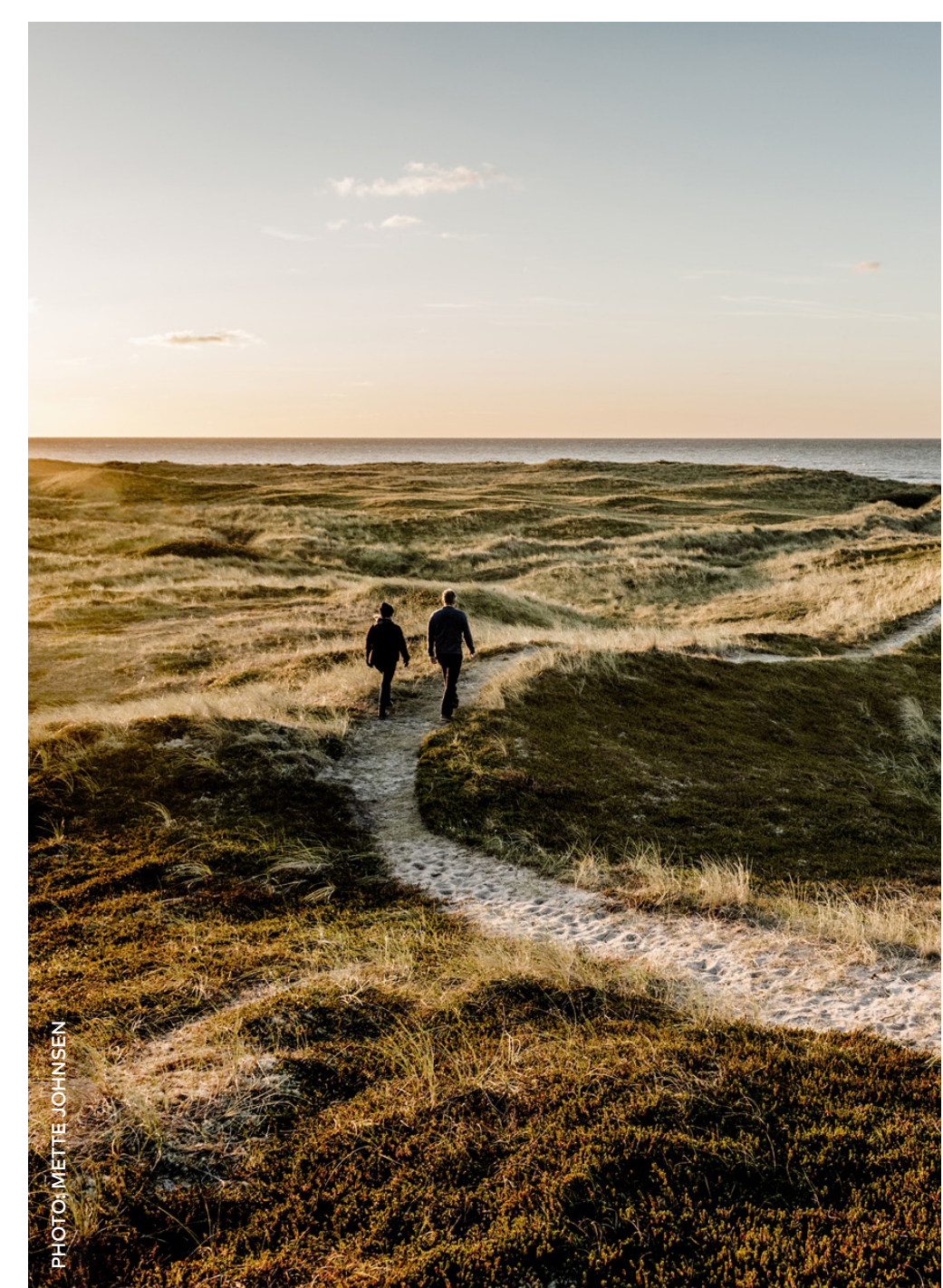

Using attractive facilities to manage visitor interactions with wildlife in THY NATIONAL PARK

Thy National Park in Denmark has a game reserve where visitors can see herds of day-active stags. The animals are popular subjects for photographs, but the large amounts of attention from visitors could potentially scare the red deer away from the area.

With funds from the National Park Foundation, the Danish Nature Agency has built a platform on the top of a hill where visitors can watch the animals without disturbing them and enjoy a great view of the park at the same time, thereby making it attractive for visitors to choose this opportunity.

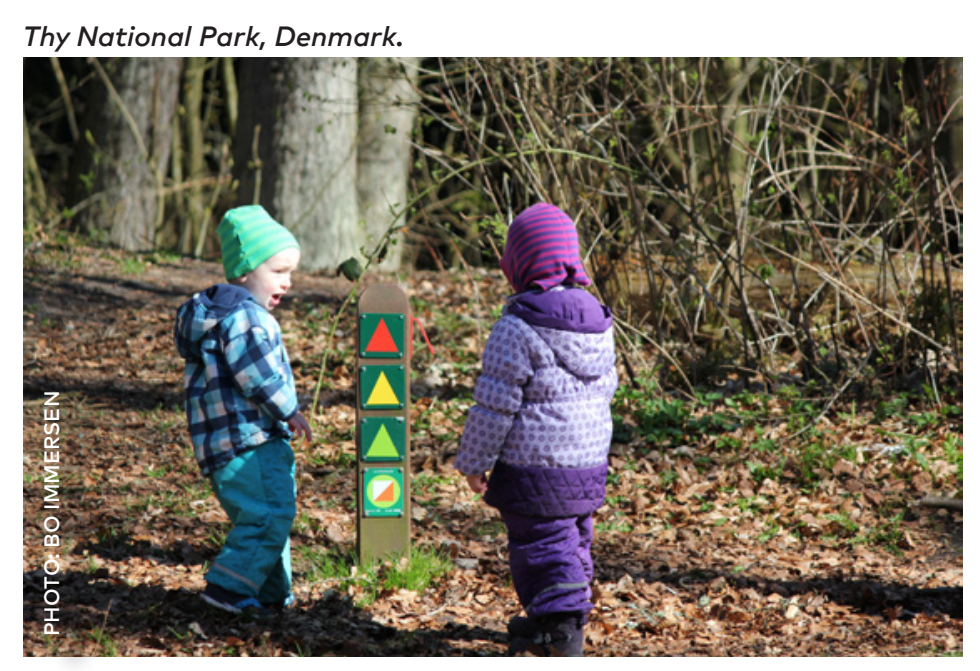

Channelling visitors through zoning in BAVARIAN FOREST NATIONAL PARK

In the Bavarian Forest National Park in Germany, almost 70 percent of the park is a designated 'nature zone' where nature is left to itself. Additionally, the park contains the socalled 'core area' where visitors have to stay on the marked hiking trails in order to not disturb the endangered species of the park. In the Bavarian Forest National Park, visitors are allowed to walk on the marked hiking trails, but no other forms of activities are allowed. The park has two visitor centres placed in the leisure zone at the edge of the park. This is where most of the visitors concentrate; they go to the visitor centre, go for a short

walk in the park, on the tree top path (facilitated by a private company) or in the animal enclosure zone, use the playground and make a stop at the café. By placing these facilities in the leisure zone, the park administration reduces visitor numbers in the more fragile nature zone and core area.

Bavarian Forest National Park Germany.

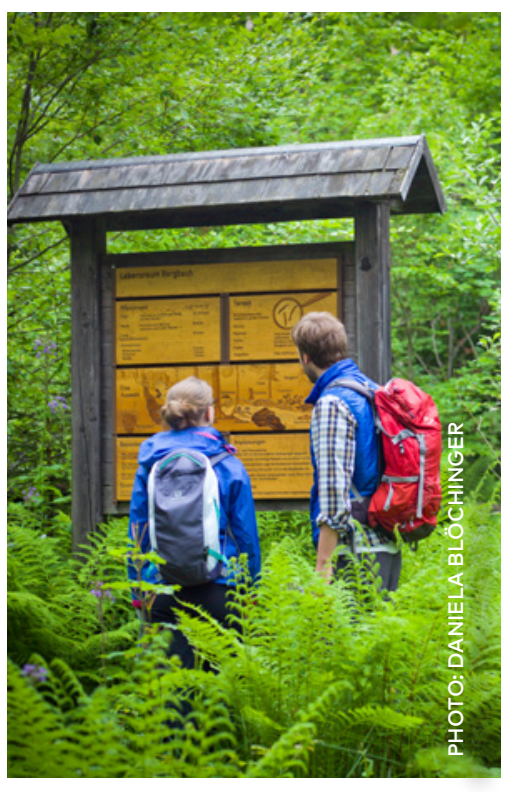


Activity-based zoning has ensured local support in FULUFJÄLLET NATIONAL PARK

The creation of Fulufjället National Park in Sweden was originally met with scepticism from the local environment. People were worried that the transition to a national park would prevent them from fishing and hunting as they had always done in this area. To address this worry, it was decided to divide the park into activity zones based on the Recreation Opportuni- ty Spectrum method. The four zones are defined according to the type of activities that are permitted or prohibited in the specific area. For example, in zone 1 , it is possible to hike and camp all year round but fishing, hunting or driving snowmobiles are not allowed. In zone 2 , hunting is allowed and in zone 3 , fishing, hunting and driving snowmobiles are allowed on marked trails. Zone 4 is the most visited and also the most restricted zone. Here, camping, hunting, fishing and riding snowmobiles is not allowed, and making a fire is only allowed in designated places.

There are no fences marking the different zones, but the different trails are marked with signs telling visitors when they are crossing a zone border. Visitors are offered free maps of the park and information about the nature and the different activity zones in the park by the staff at naturum Fulufjället ${ }^{14}$.

${ }^{14}$ Naturum is an information centre at the entrance of most Swedish National Parks, operated by the Swedish Environmental Protection Agency.
The zoning has made it possible to counter the local scepticism, turning it into local support by maintaining areas for hunting, fishing and riding snowmobiles while also creating areas for recreational purposes.

\section{Recreation Opportunity Spectrum (ROS)}

The Recreation Opportunity Spectrum (ROS) is a system for classifying and managing recreation opportunities in an area based on the following criteria: physical setting, social setting, and managerial setting. The combination of the three criteria results in six different ROS classes that are: Primitive, Semi-primitive non-motorized, Semi-primitive motorized, Roaded natural, rural, urban.

The method indicates where different types of user activities are allowed or encouraged and can be used to define different types of activity zones in a recreation area, guiding sustainable recreational planning and management.

Read more

Fulufjället National Park, Sweden. 
Mobile information points target day-to-day visitor management challenges at the NEW FOREST NATIONAL PARK

In the New Forest National Park in Great Britain, there are a number of mobile information points in the shape of small vans. These mobile information points can be moved around the park on a day-to-day basis and be placed in 'hot spots' that present a particular visitor management challenge. The vans are manned by a staff member and a volunteer guide from the park and the side flips open, turning the van into an information stand with a park map and information. The manned vans are visible and inviting to the visitors and provide on-the-spot information and advice to address any potential problems relating to e.g. over-crowding or particularly vulnerable wildlife.

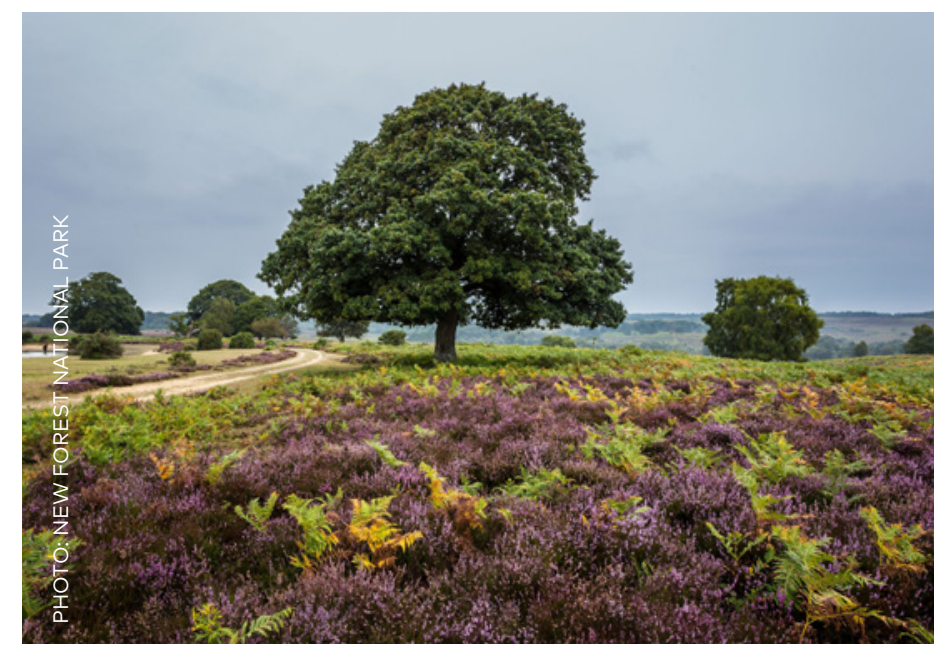

New Forest National Park, Great Britain.
Local tourist entrepreneurs

as guides at

FULUFJÄLLET NATIONAL PARK

At Fulufjället National Park in Sweden, the nature guide service is run by local tourist entrepreneurs. The park staff trains the

guides according to park principles of nature education and makes sure that the guides have the information they need.

This not only creates local

jobs, but also ensures that the visitors in the park are

offered the opportunity

to learn about the specific nature at Fulufjället National Park from qualified nature guides. In high season, they have a daily guided tour that people can join, and in the shoulder seasons, the tour runs a few days a week. The number of participants varies and is usually between 5-10 persons. Information about the guided tours is available at the naturum and on Fulufjället's website and Facebook page. According to feedback, visitors find that the guided tours give them a better understanding of the nature in the national park.

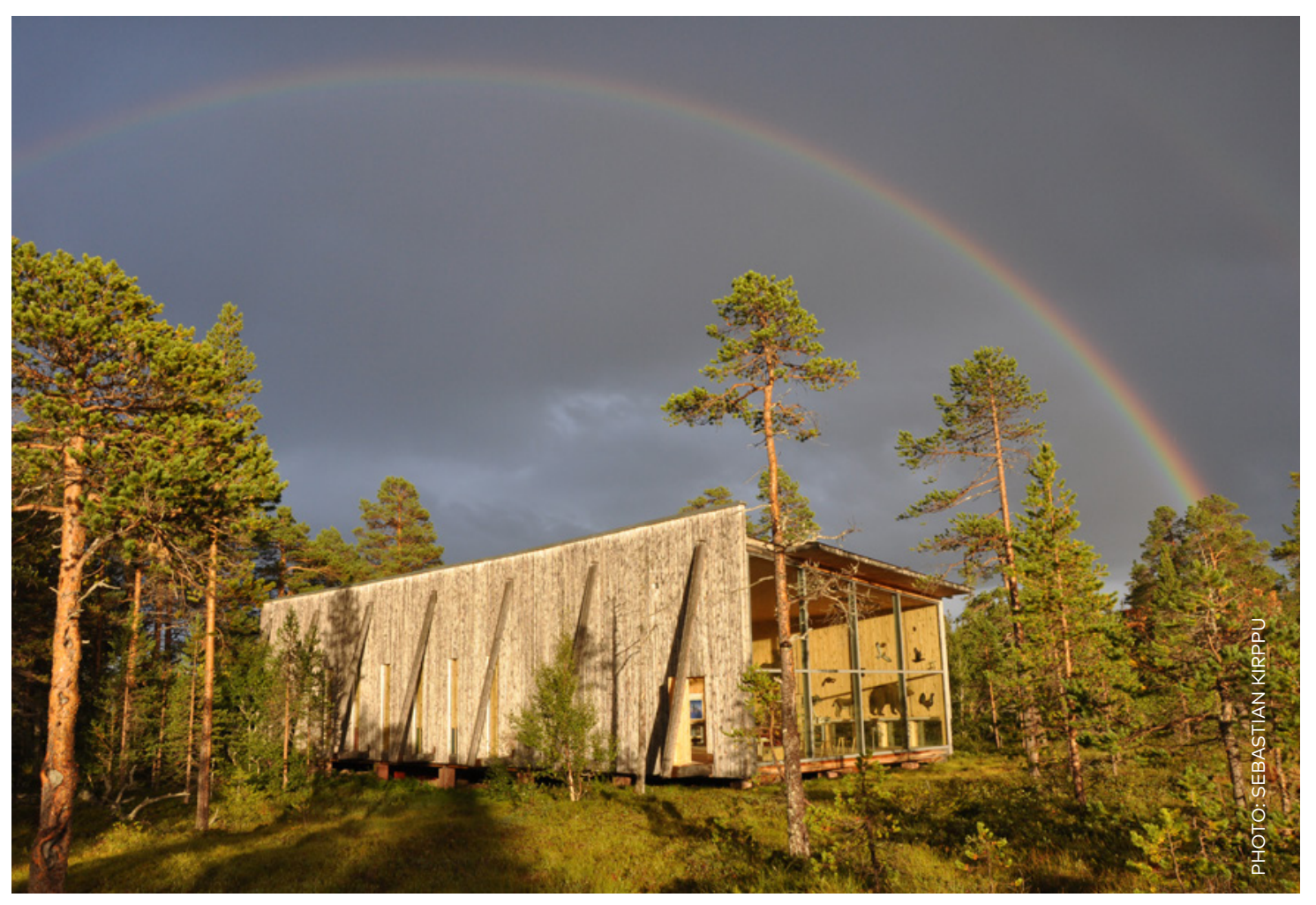

Fulufjället National Park, Sweden. 


\section{Path patrol pilot project at the BESSEGGEN RIDGE IN NORWAY}

The Besseggen Ridge, an attraction in Jotunheimen National Park, has almost doubled its number of visitors in five years. In 2018, nearly 70,000 people visited the area, and about 57,000 hikers were counted along the path over the ridge. Besseggen is a large and robust area, and the carrying capacity of the nature and the landscape is not threatened by the many new visitors. However, the increase in visitor numbers

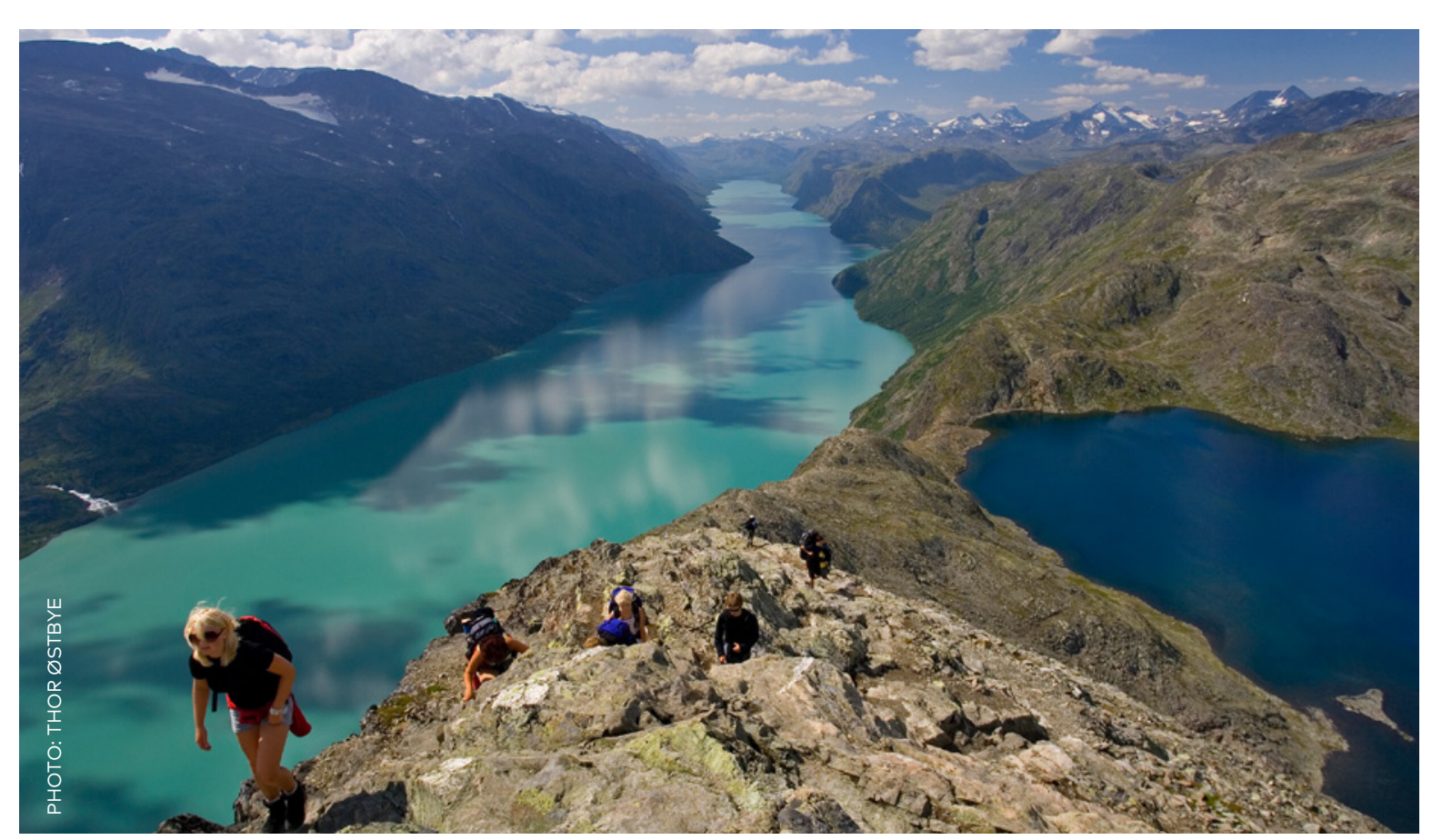
financed by over 20 local tourism businesses and two municipalities was launched in 2017. The idea was to have on-site personnel to help exhausted and frightened tourists down from the ridge or by gentle means (conversations, biscuits and coffee) motivate them to manage the most challenging parts of the ridge. The path patrol is an independent limited company, and the services they provide are considered a common good. The staff is highly skilled in first aid, mountain medicine and general outdoor life.

The patrol prevented several rescue operations by police and helicopter in 2017. It

Besseggen Ridge, Jotunheimen National Park, Norway. also collected litter and carried out basic repairs of the path when necessary. This was done in close understanding with the national park management.

In 2018, Oppland County applied for and received funding from the newly established National Tourist Paths programme, under the Norwegian Environment Agency ${ }^{15}$. The county channelled money from the programme into the path patrol to match the financing from the local tourism businesses and the municipalities. With this funding, the patrol was able to walk the ridge twice as many times as in 2017. Preliminary statistics from the 2018 season show that the number of rescue operations were halved compared to 2016.

Under the National Tourist Paths programme, Oppland County also received funding for developing a visitor management plan for the area. This will be done in collaboration with the National Park management. The Environment Agency has also made authorisation criteria for the National Tourist Paths. The criteria will be operational from 2019.

${ }^{15}$ National Tourist Paths focuses on the protection and care of nature and experience values of nature areas that receive an exceptionally large number of visitors and thus face problems such as path erosion, littering, over-crowding, safety issues, etc. The purpose of the subsidy is to contribute to better and more integrated visitor management in these nature areas. Read more about the Norwegian National Tourist Paths here:

http:/www miljodirektoratet no/no/Tema/Frilufts/iv/Nasjonale-turiststier/ 


\section{Volunteer programmes in the} NEW FOREST NATIONAL PARK

In the New Forest National Park in Great Britain, 250 volunteers play a key role in the park's visitor management by offering guided walks and manning mobile information points, among many other things. Besides offering a great service to park visitors, the volunteer programme is also part of a strategy to engage the local and regional population in the protection of the park, thus creating local and regional support for the park. The New Forest National Park points out that working with volunteers is a full-time job that requires prope management in regard to solving safety issues, coordinating shifts, managing expectations, etc.

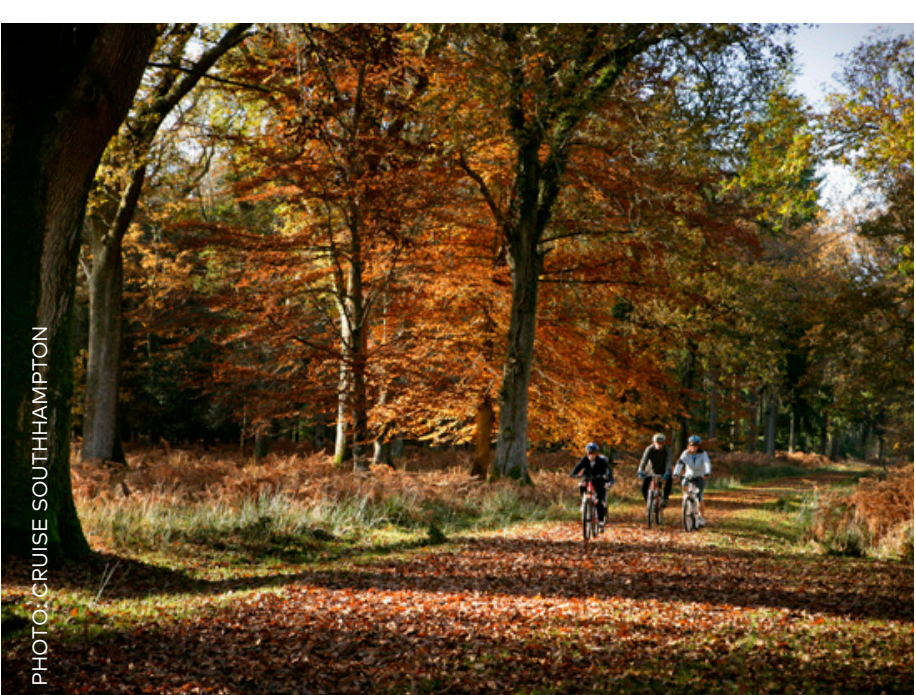

New Forest National Park, Great Britain.
Educating volunteer forest guides in the BAVARIAN FOREST NATIONAL PARK

In the Bavarian Forest National Park in Germany, around 100 volunteer forest guides offer guided visitor tours. These forest guides must be certified through a two-week education programme followed by a test, where they learn about park nature, landscape and wildlife, hosting and service, etc. The education programme is followed up by yearly training Forest guides are recruited among the local population with the purpose of making them strong, local ambassadors of the park. Around 20 years ago, the local population had a much more negative attitude towards the park and struggled to understand its purpose. The involvement of local volunteers has helped change the local attitude towards the park in a much more positive direction. It also makes it possible for the national park to offer a large number of guided tours every year while creating an additional source of income for the locals.

\section{Children volunteer programme}

The park has a Junior Ranger Programme where 11-year-old children accompany a ranger for one week during summer. The Junior Ranger Programme is a EuroParcs initiative and used in parks across Europe. The idea is that the children learn about the park and its valuable nature and cultural heritage. This creates ownership and a sense of responsibility towards the park from an early age, and the children act as enthusiastic ambassadors for the national park around their families and friends. Since 1998, the junior ranger programme has had around 3,000 participants. After the first week, the children have the option to join the local Junior Ranger Association that offers nature-based leisure activities such as monthly hikes in the national park, and as young adults, they can continue their engagement in the park by joining the Volunteer Ranger Programme.

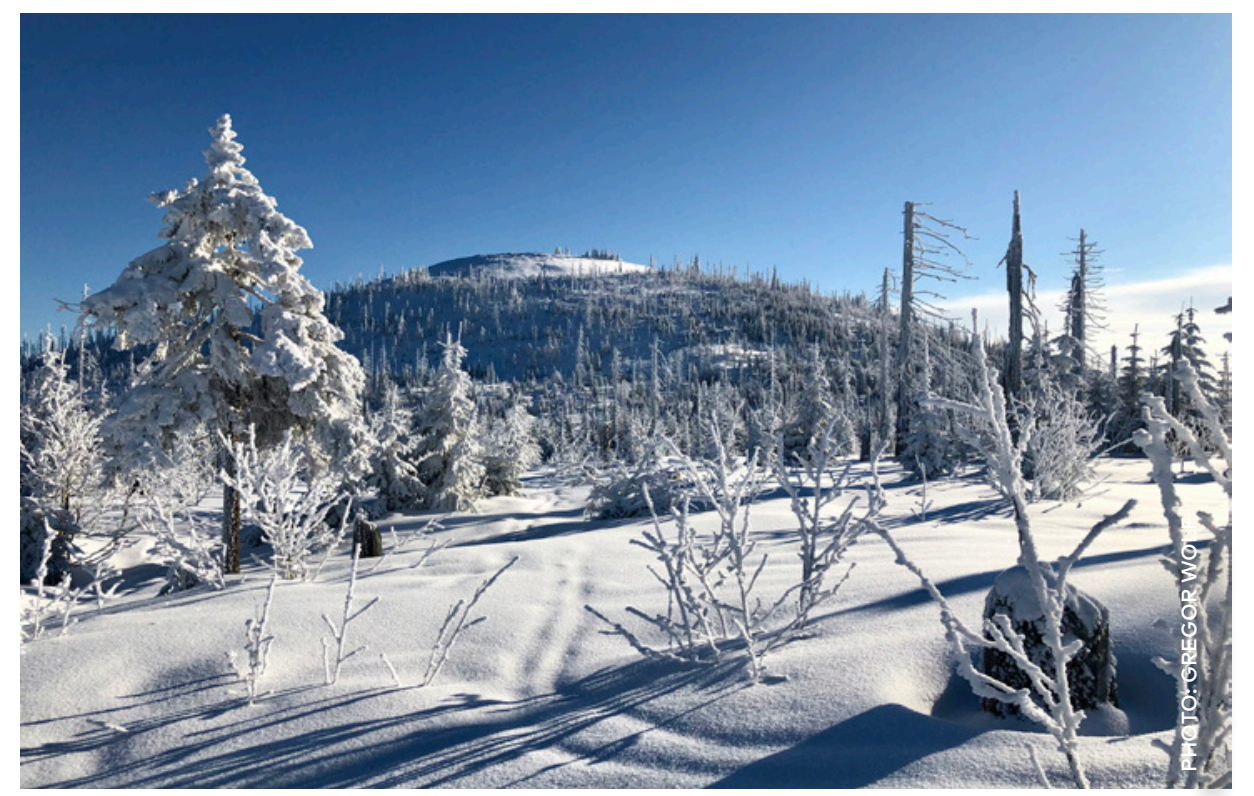

Bavarian Forest National Park, Germany. 


\section{A coordinated information effort to spread} visitors at

\section{WEERRIBBEN-WIEDEN NATIONAL PARK}

The village Giethoorn, also referred to as "The Venice of Holland", close to Weerribben-Wieden National Park in the Netherlands, has become a very popular tourist destination, especially among Asian visitors. This has created problems with over-crowding in high season, which has led to dissatisfaction in the local population. In a coordinated effort, the park is working on spreading visitors to other areas of the

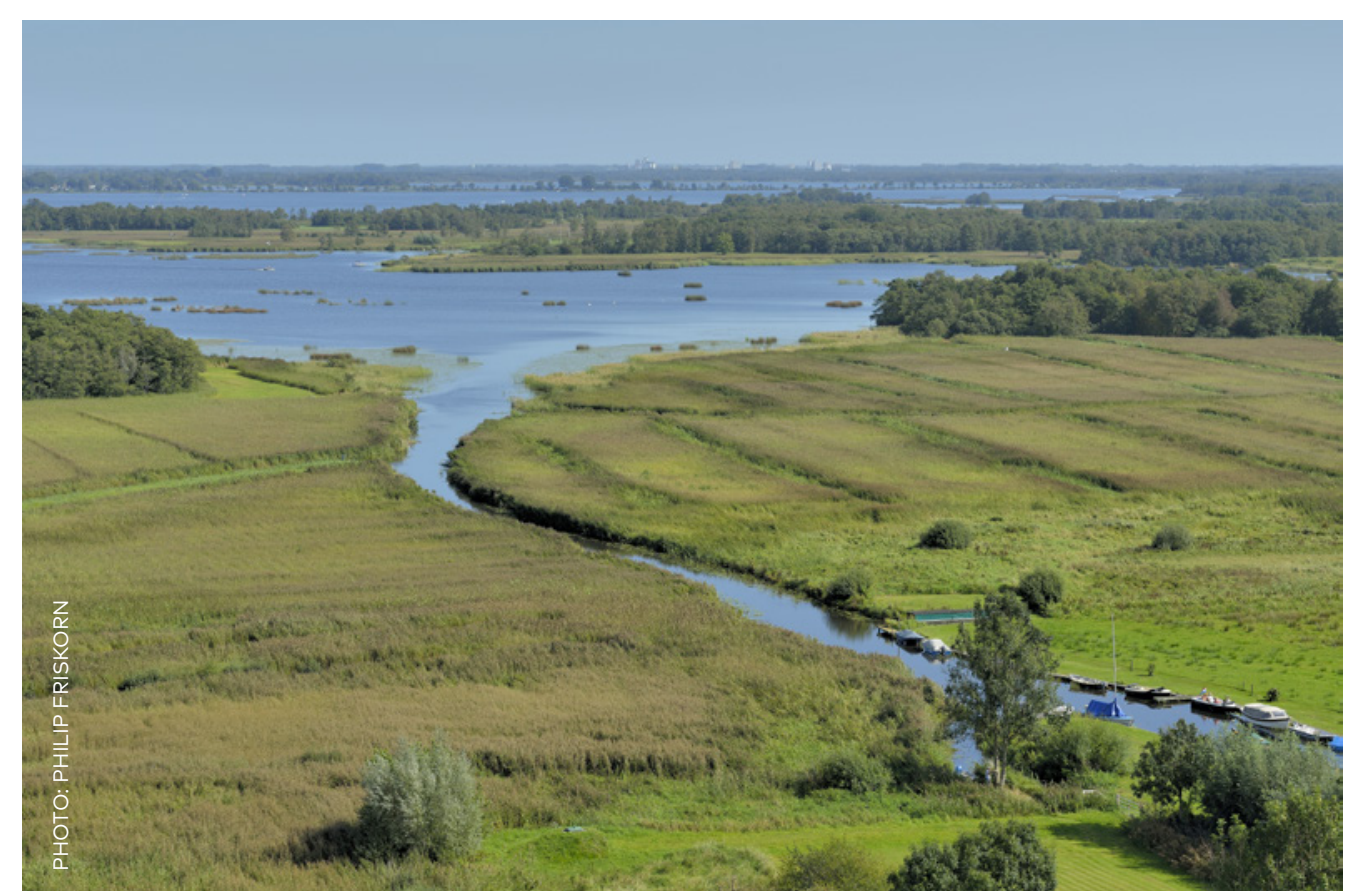

park using signs, brochures and front desk staff at the most popular tourist spots in Giethoorn to inform visitors about alternative park sites. This coordinated effort is showing positive results so far, as visitors are successfully spreading to other parts of the park, taking some of the pressure off the 'hot spots' of Giethoorn.
Weerribben-Wieden National Park the Netherlands.
Systematic visitor registration makes one-to-one visitor information possible in SVALBARD

The Norwegian archipelago Svalbard has seven national parks. The total area covered by the national parks is enormous

compared to the number of supervising staff members, and infrastructure is sparse. This makes it difficult for both visitors and staff to move around easily. The nature is unspoiled and rough, but also fragile. Hence, it is important that visitors be provided with a basic knowledge of the landscape and animal life and the challenges they might encounter before venturing into the parks on their own.

Within management area 10, visitors can walk freely without registration, but if they want to leave this zone they need to register at the governor's web page and pick up a registration card at the governor's office. Here, the staff will use the opportunity to give the visitors a one-to-one information and advice about the nature of Svalbard and the codes of conduct. This

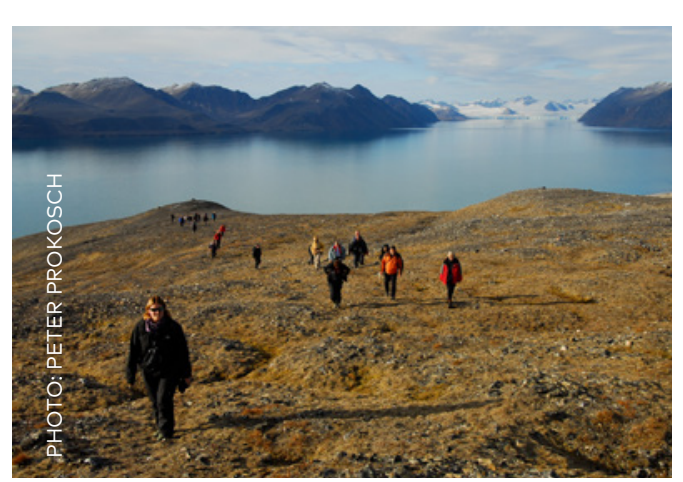
has proven to be an effective way to inform as many visitors as possible and prepare them for their experiences in Svalbard. Svalbard, Norway. 


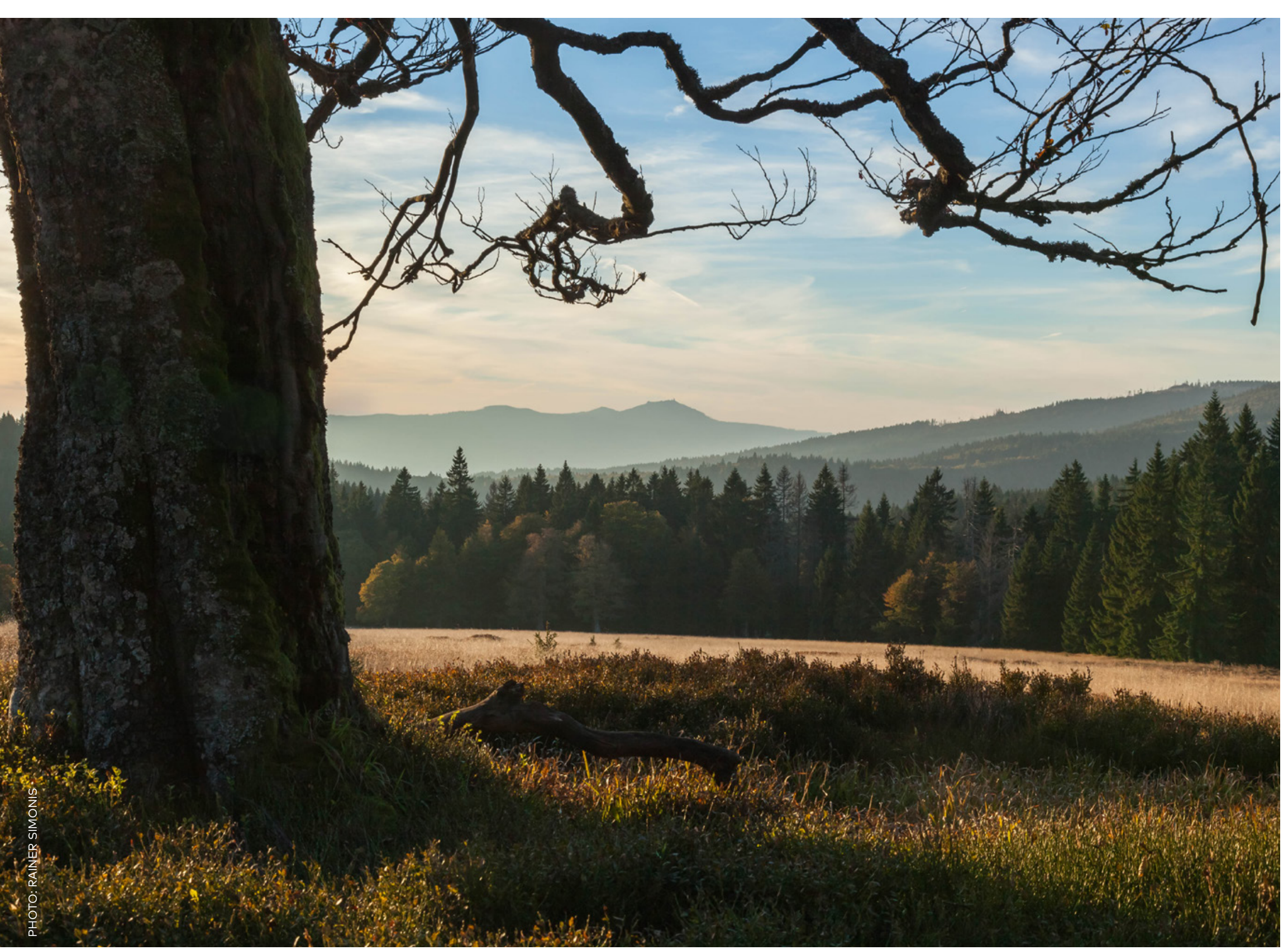

SOLUTION 3

\section{Online} communication and PR

This chapter presents examples on how national parks work with online communication and $P R$ in an effort to educate visitors in an engaging way and use strategic communication to help spread awareness and create local ownership. 


\section{Educational videos in \\ NORWEGIAN AND ICELANDIC \\ NATIONAL PARKS}

Both Inspired by Iceland (a marketing initiative under Promote Iceland) and Visit Norway have identified a need to educate visitors on what they need to be prepared for when faced with the nature, culture, landscape and weather conditions of the national parks and nature areas in these two countries, and both organisations have chosen to use web-based video material to do this in a fun, easy and engaging way. The videos are informative but informal and short, and they have a visual and humoristic quality that make them more likely to be viewed and shared among users.

Inspired by Iceland has made a series of six videos under the headline Iceland Academy. Each video is a humoristic lesson where a teacher guides the visitor through a range of situations, e.g. what to wear, how to avoid accidents when taking selfies in front of the geysers and how to behave in a socially acceptable way in the Icelandic hot tubs.

www.inspiredbyiceland.com/icelandacademy/
Visit Norway has made a series of videos called Safety first A guide for safe mountain hikes during the summer in Norway where a professional nature guide demonstrates how to pack and what to consider when hiking in the Norwegian mountains. There are eight videos in total. The first three focus on essential hiking do's and don'ts such as what to wear, what to bring and how to behave, and the last five videos give specific information and tips about five popular hiking routes and sites. Since the release of the videos, the number of rescue operations has dropped at many of the popular sights, although the correlation between the two has not been documented officially.

www.youtube.com/user/visitnorwaycom
PR department has created awareness and local ownership in

\section{BAVARIAN FOREST NATIONAL PARK}

In the Bavarian Forest National Park, the PR department em ploys two full-time journalists and an assistant. The department is responsible for driving the PR and communications strategy of the park, e.g. managing its Facebook page and Instagram account, getting stories in the local news media, host journalist visits, film teams and so on. The strong focus on PR and communication has helped spread general awareness and knowledge of the park and has also supported the acceptance of the park in the local population, e.g. by explaining to the locals the importance of leaving dead trees as part of securing the biodiversity of park nature.

Bavarian Forest National Park, Germany.

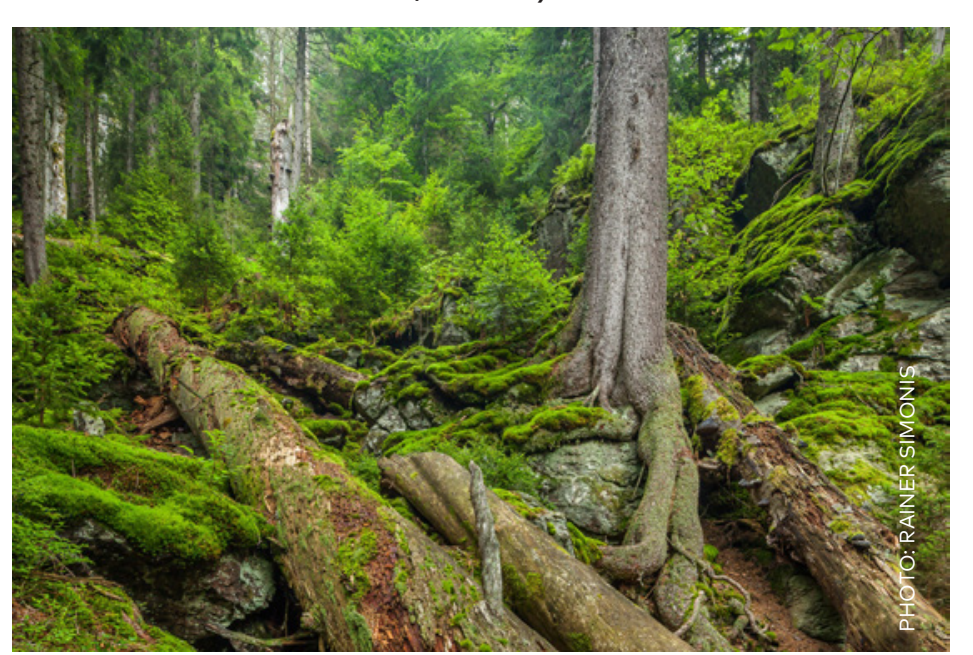




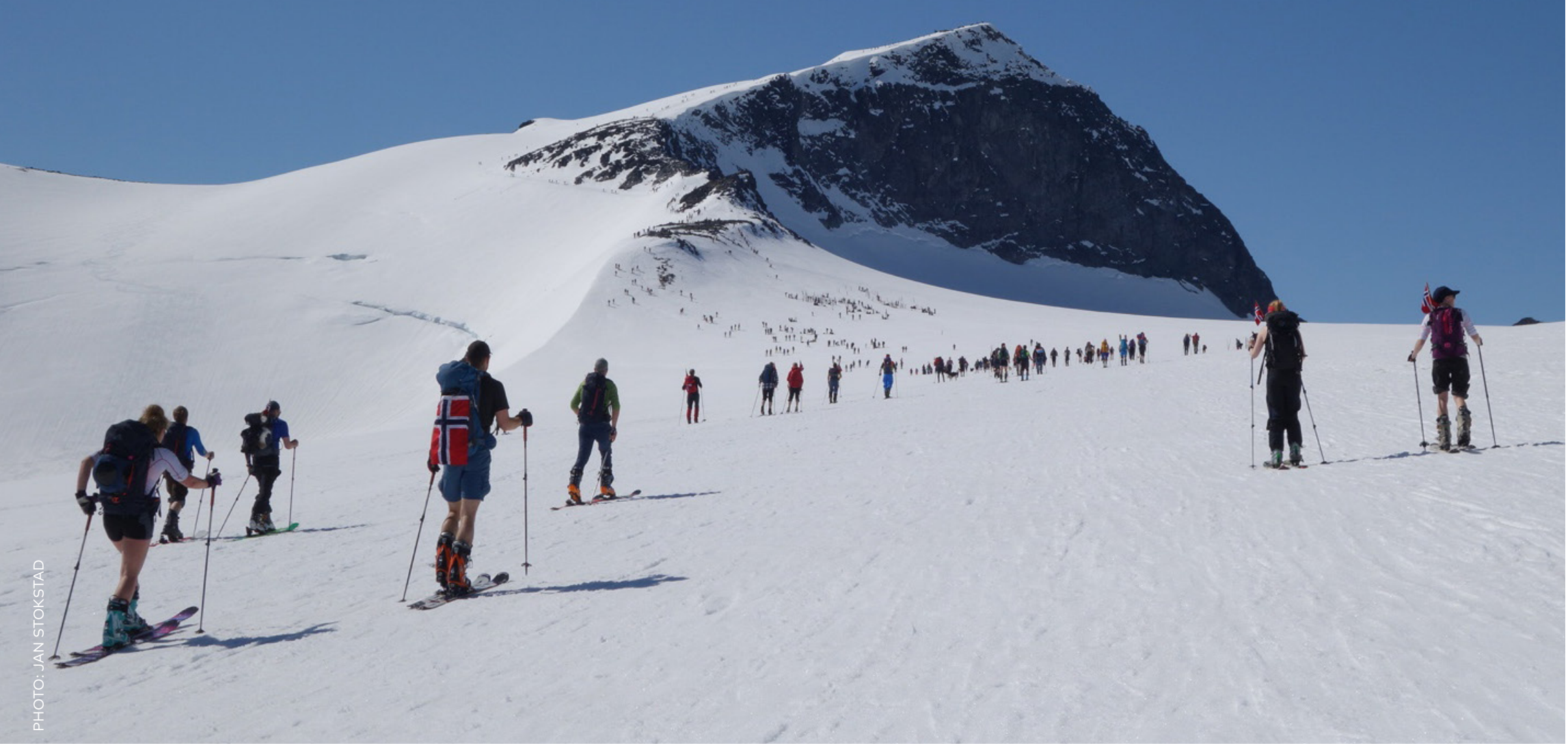

Site-specific guidelines and codes of conduct

Often, site-specific guidelines and codes of conduct are used in areas with a particularly vulnerable nature or cultural heritage where a certain behaviour is required in order to protect the values of the nature and the landscape. The examples in this chapter show that the impact of such guidelines increases if they are developed in close cooperation with key actors such as end users, tourism actors and researchers, each bringing their own valuable perspective on how to obtain the ideal balance between use and protection. 


\section{When tourist operators lead the way for sustainable tourism behaviour in SVALBARD}

AECO (Association of Arctic Expedition Cruise Operators) is an international association for expedition cruise operators operating in the Arctic. AECO's members specialises in ship based tours to the arctic areas. AECO functions as an interest organisation for its 70 members but is also an environmental organisation working to find solutions for making tourism more sustainable. AECO's principles of sustainability are centred on four main objectives: safety, local communities, culture and the environment - such as nature, flora, fauna and cultu-ral remains.

Among other initiatives AECO work together with UN Environment to fight marine plastic pollution and engage cruise passengers to get involved in beach clean-ups as well as cut-backs on single-use plastic on cruise vessels that carry out Arctic expeditions. During the summer of 2018 AECO's members have managed to significantly reduce the amount of single use plastics and other items on board the 50 AECO member vessels that annually operate in the Arctic. During the past almost 20 years of work with beach clean up AECO operators have removed many tonnes of plastic from the region - particularly through the AECO member initiated Clean Up Svalbard Program.

AECO has developed a set of site-specific guidelines for cruise ship tourists in Svalbard, communicating the guidelines to all their cruise operator members. The development of these guidelines is based on a research project by the Norwegian
Institute for Nature Research (NINA) that has developed a model for measuring and assessing the vulnerability of vegetation, animal life and cultural heritage for a number of locations in Svalbard. The model is developed in cooperation with the governor of Svalbard and AECO and comes in the shape of an easy-to-use handbook. The handbook has also been used to develop management plans for Svalbard. AECO currently have almost 30 site-specific guidelines for Svalbard and the Russian Arctic which are mandatory to use for all AECO's members.

In many cases, the site-specific guidelines for Svalbard are stricter than the regional and national standards for nature preservations. But as AECO argues, "our industry does not have a future, if we are not proactive on this matter". The aim of AECO's work is not just to make the arctic tour operations sustainable, but also to inspire politicians and local/national decision makers to constitute policies that comply with AECO's standards.

So far, there are site-specific guidelines for more than 30 destinations in the Arctic. The guidelines describe the natural and cultural values of the specific site and explain what visitors are allowed

\section{Svalbard,} Norway. to do, what is prohibited at the site and why. This tool has been working well so far and the plan is to continue with the development of more site-specific guidelines for other sites at Svalbard.

AECO has many other types of guidelines than the sitespecific guidelines, among others biosecurity guidelines, wildlife guidelines and community guidelines

(see: www.aeco.no/guidelines/). All of AECO's guidelines are mandatory to use for AECO's members.

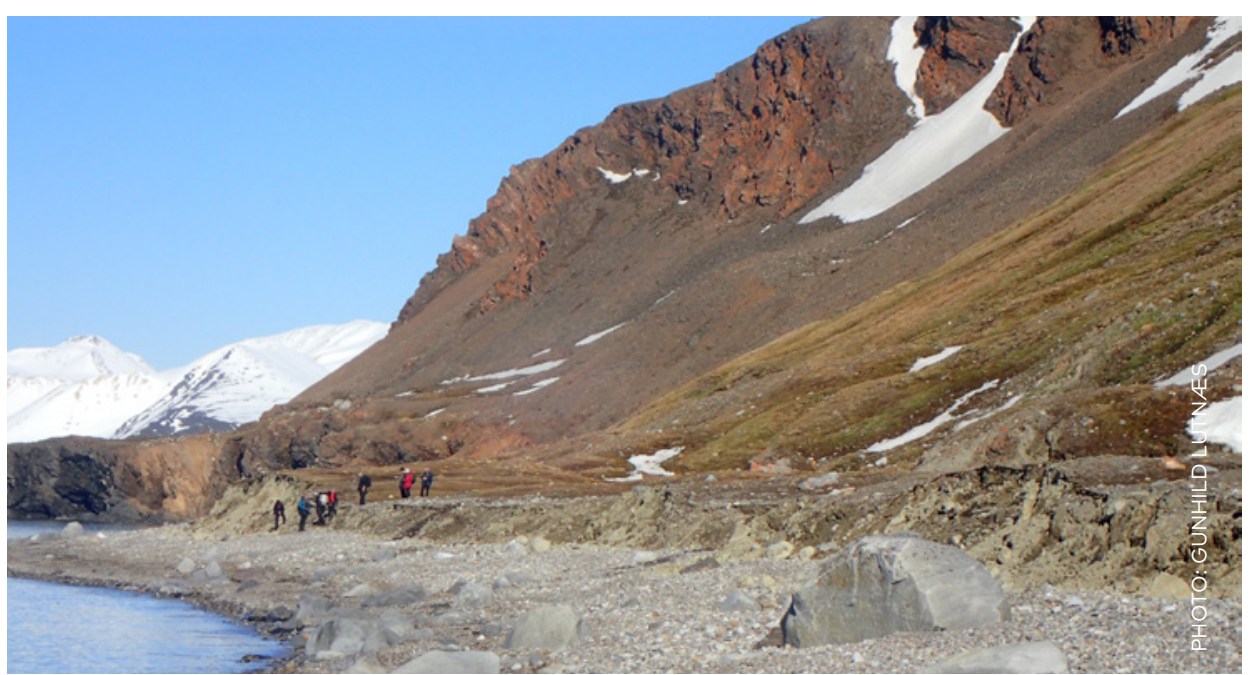




\section{Cocreating site-specific guidelines with users in SKJOLDUNGERNES LAND NATIONAL PARK}

Skjoldungernes Land National Park in the populated area around Roskilde Fiord in Denmark is currently working together with different user group associations to create site-specific guidelines. At Skjoldungernes Land National Park, the fiord is especially challenged when it comes to nature preservation. In the park, many different user groups use the water (kayaks, windsurfers, paddleboards), the visitor numbers are increasing, and new types of activities such as motor-driven paddleboards are expected to become a challenge in the near future.

At the same time, the area is inhabited by birds that are very vulnerable during the breeding season. To address these challenges, the park administration is meeting with different water activity associations and clubs to create a brochure about appropriate behaviour. This collaboration is also aimed at helping the implementation of the park's code of conduct principles (currently under development) among the use groups. At the same time, this process has given the park more knowledge about the user groups and their needs, which enables the park to better understand how to plan for and involve these groups.

Skjoldungernes Land National Park, Denmark.

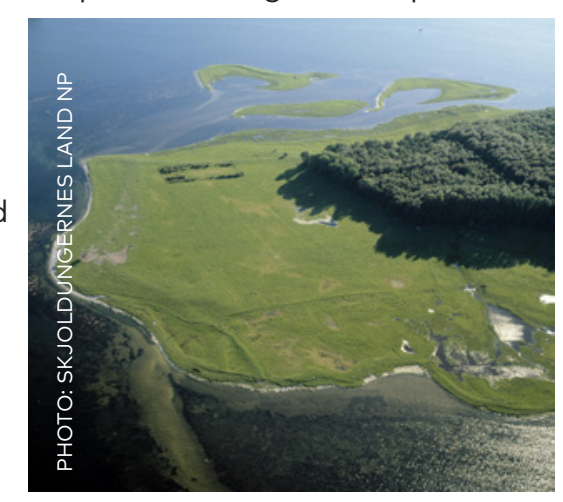

\section{User-driven code of conduct process at THE WADDEN SEA NATIONAL PARK}

As part of a code of conduct project, the Wadden Sea National Park in Denmark has initiated a series of workshops with relevant user groups and their local associations including horseback riders, mountain bikers, hunters, kayakers, water skiers and beach guests.

At the workshops, knowledge, opinions and experiences on different subjects are shared: What is the user group's specific needs when carrying out their activities in and around the national park, what kind of conflicts do they experience with other users, what does the park want them to know, etc. The purpose of the workshops is to formulate a code of conduct for each user group, to help the associations communicate these codes of conduct to their members and visiting users and to establish small local networks for continued knowledge sharing. The project also aims to instill a sense of responsibility towards and shared ownership of the natural and cultural landscapes of the park. The workshop participants have shown great interest in the project.

The Wadden Sea National Park also plans to create a code of conduct for general guests in the area, which is to be communicated through various channels, including the tourist organisations.
In addition to creating guidelines for guests and recreational users, the park will work on a set of guidelines for local tour and nature guides and nature centres, which focuses on safety and quality experiences for the guests through a sensitive and appropriate approach to being in nature. The park also hopes that the centres will be engaged in a project focusing on teaching - especially local - children about the special nature of the Wadden Sea and how to interact with this nature in a sustainable way.

The Wadden Sea National Park Denmark.

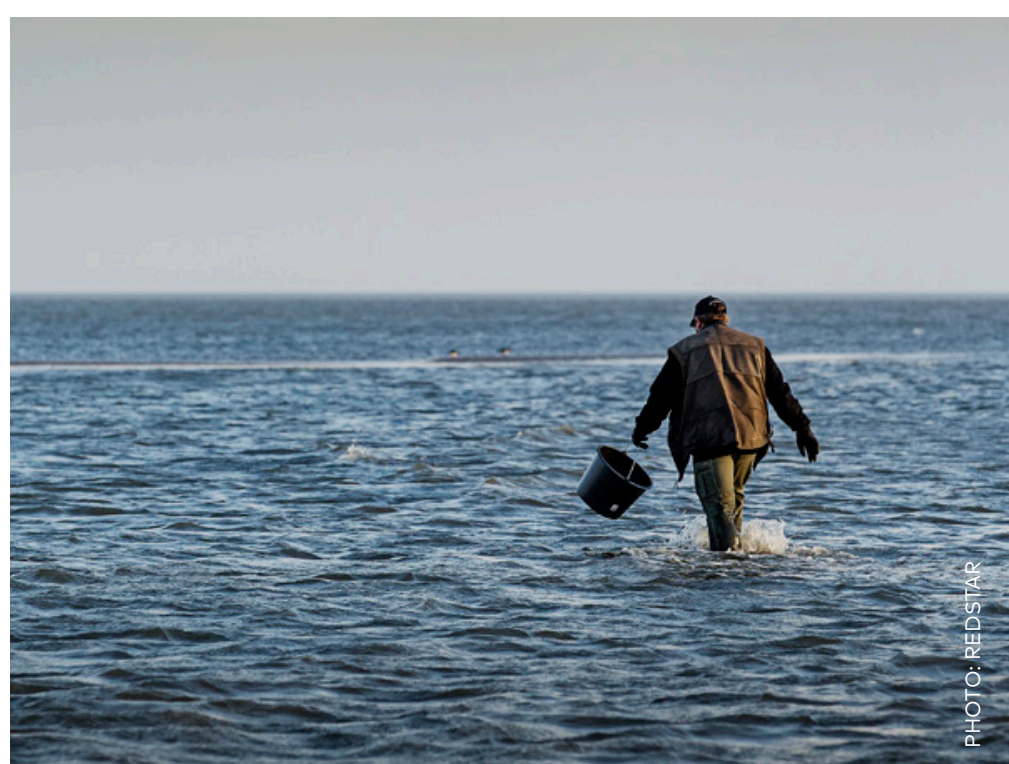




\section{Certification of paths as a branding and service} strategy

\section{THE BAVARIAN FOREST NATIONAL PARK}

The Bavarian Forest National Park in Germany is in the process of going through a certification programme offered by the German hiking association. The 350 kilometres of hiking paths are already clearly marked and easy to follow, but the certification is done for marketing reasons and as a service to the visitors, making it simpler for them to choose an experience suited to their wishes and needs.

Five hiking trails in the park are each getting a different certificate. The park offers a barrier free trail, a trail for families with playing activities, a trail for ambitious hikers, a trail for visitors who want to experience special nature and wilderness, and a trail for experiencing regional food culture.

The certification is also a tool for spreading visitors more evenly in the park by directing visitor focus to alternative routes and experiences.

Bavarian Forest National Park, Germany.
The use of 'hard' safety standards and restrictions for scuba divers in THINGVELLIR NATIONAL PARK

At Thingvellir National Park in Iceland, a private tourist business is running a scuba diving/snorkeling guide service at the Silfra Fissure. Silfra is a very popular spot for scuba diving and snorkeling, but there have been some challenges concerning safety, which has unfortunately led to fatal accidents.

At the same time, the national park's committee (Pingvallanefnd) has agreed on restrictions and rules regarding diving and snorkeling in Silfra. There is a limit to the number of divers and snorkelers allowed to enter the fissure at the

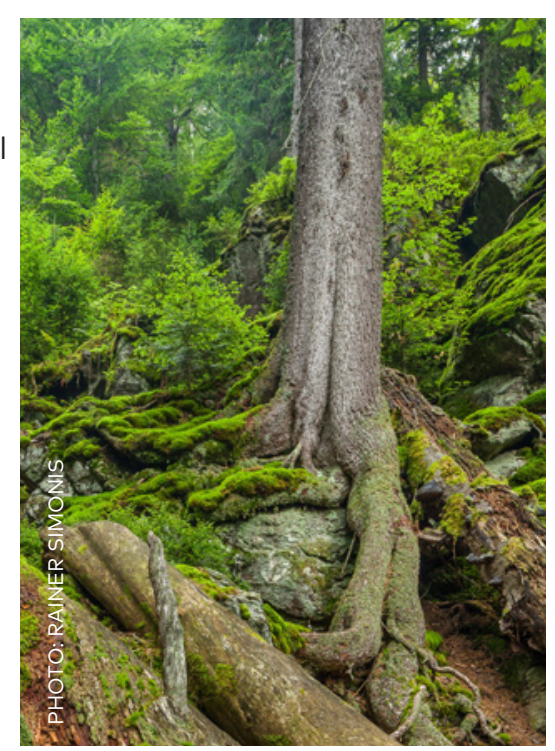

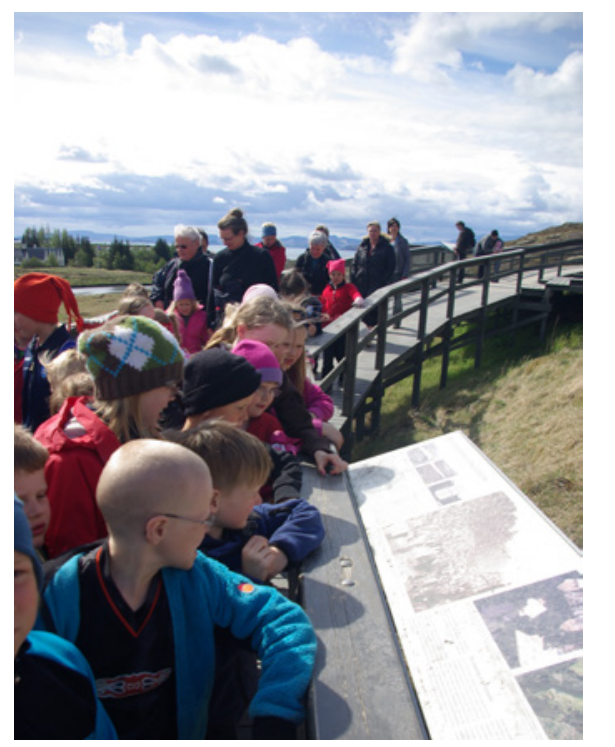

same time, and this number has recently been lowered from eight to six people in a snorkeling group and from four to three people in a diving group. In addition, there has to be a certain space between the groups. No one is allowed to dive deeper than 18 metres. Together, the enforced standards and restrictions have led to a higher level of safety at the scuba diving site.

\section{Thingvellir National Park, Iceland.}




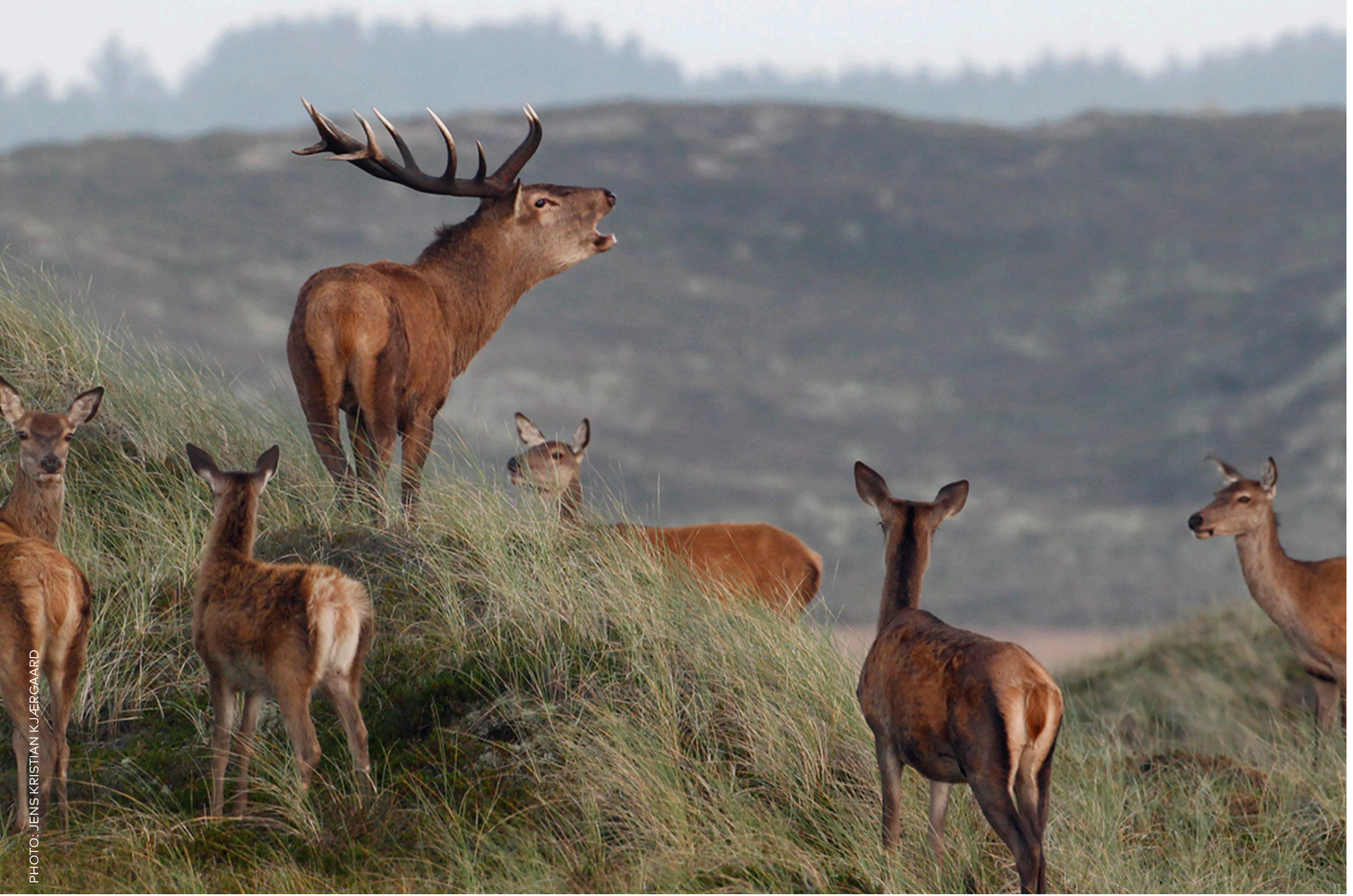

\section{Stakeholder partnerships}

Establishing a strong relationship with the national park stakeholders is key to creating a strong foundation for better and more sustainable visitor management. As the examples show, this can be done in a variety of ways: annual tourism forums for the small, local tourism businesses, discovery days where front desk staff from local businesses are educated on park values and experiences, a destination organisation formed by the national park and key tourism business partners that work together to strengthen the local tourism value chain, national park partnership models and education programmes for locals, businesses, volunteer guides, schools, etc. and the involvement of local stakeholders in the development of strategic plans. In all of these examples, the effort to inform, educate and involve the local stakeholders has helped build local ownership, pride and a sense of responsibility towards the value of the park, which benefits the protection of the national park and offers visitors a better experience.

Thy National Park,

Denmark. 
The annual Tourism Forum inspires local tourism businesses

\section{YORKSHIRE DALES NATIONAL PARK}

Yorkshire Dales National Park is situated in a rural part of Great Britain, north of Liverpool and Leeds, two of England's largest cities. The area is faced with some of the usual rural challenges concerning employment in the Yorkshire Dales, which is dominated by the agriculture, accommodation and food sectors. Many jobs are seasonal, and this can make for a lack of year-round employment and may lead to people commuting or relocating to other locations in the region for employment. This is also why a main focus area of the national park is to help keep local communities thriving in close cooperation with the local authorities in the national park.

One way of doing this is to help develop the tourism businesses in the area. Most of the tourism businesses are small and have limited resources available for developing new sustainable products. Once a year, the national park organises the Annual Yorkshire Dales Tourism \& Outdoor Providers Forum, where 90 different partners come together and hear about and share best practices. The tourism businesses learn from each other and get inspiration from working with the national park. Following the forum, the delegates are asked for feedback, which enables the National Park Authority to provide workshops and training for the tourism businesses. For example, an astrotourism expert was commissioned by the National Park Authority to deliver a workshop on how to get the most from dark skies tourism, and many businesses now use this as an added attraction for their customers. Then, the businesses are asked to share their experiences and best practice via networking activities and by giving presentations to other businesses at the annual Destination Dales forum. Some of the businesses will also be promoted on the National Park Authority website as a 'Brilliant Business' case study for more information on this, see: www.yorkshiredales.org.uk/ living-and-working/other-services/ tourism/brilliant-businesses

Yorkshire Dales National Park, Great Britain.

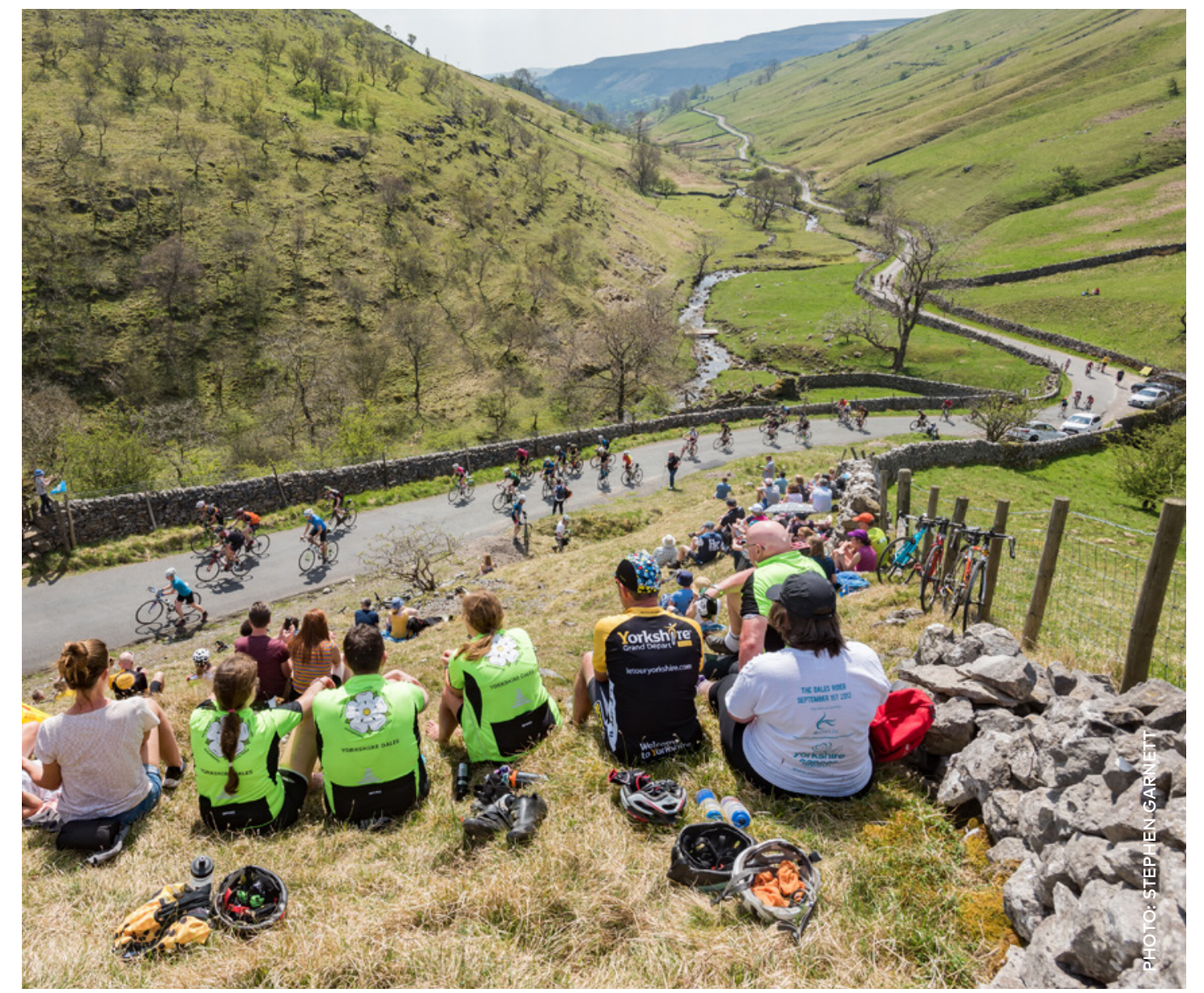




\section{Destination Dales - Bringing Business to \\ Businesses \\ YORKSHIRE DALES NATIONAL PARK}

One of the biggest challenges in Yorkshire Dales National Park in Great Britain is to keep the local communities thriving and keeping the local schools running at a time when especially young people move to the bigger cities. One way to take part in developing the local environment is by improving tourism and supporting the many local tourism businesses.

This, along with the earlier work to achieve the European Charter for Sustainable Tourism in Protected Areas, has resulted in the setting up of an advisory group called Destination Dales. The aim of Destination Dales is to support the aspirations of the National Park Management Plan, which aims to increase the volume and value of inward tourism to the Dales businesses and to ensure that the benefits brought to the area by tourism are optimised, while at the same time safeguarding the special qualities of the Dales.

Destination Dales is a partnership between Yorkshire Dales National Park, Nidderdale Area of Outstanding Beauty and the local authorities at the National Park plus private sector members (one of them runs a tourism network with 500 members). The group's executive is drawn from key organisations, including volunteers from tourism businesses.

The Destination Dales Group board members meet approximately 4 times per year to look into training needs, resources for businesses and how local businesses can benefit from joint campaigns. The group shares ideas, provides a forum for discussion and offers guidance on product development, promotion development and people development. Perhaps most importantly, the group has been a key voice in contributing to the tourism objectives in the National Park Management Plan and has been involved from the beginning to the end of the process.

Yorkshire Dales National Park

Great Britain.

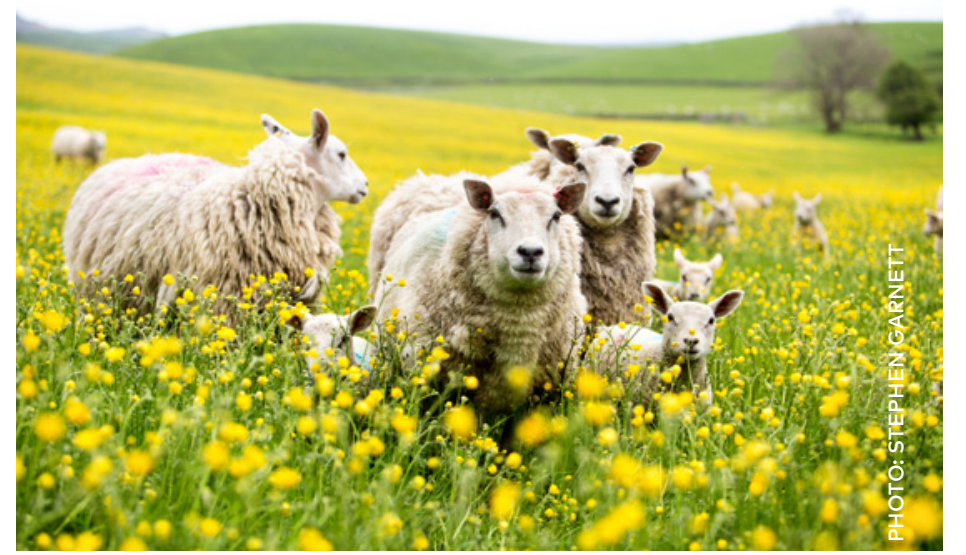

Discovery Days for tourism businesses create local ambassadors

\section{NEW FOREST NATIONAL PARK}

Four times a year at the New Forest National Park, the park administration hosts an event called Discovery Days for the front desk staff from the local tourism businesses and shops. The purpose of the Discovery Days is to pass on knowledge about the park's nature and teach front desk staff how to talk to customers about park values and experiences. Themes may include 'A day on a farm', 'Meeting the commoner', 'Going for a short walk', 'Wild life and ground nesting birds', 'Deers'.

They repeat the themes and programmes every now and then to get new shop staff members on board. An average of around 15 local shops join every Discovery Day, and the result is a network of strong national park ambassadors among local business owners that extends and strengthens the visitor management and service of the park.

A challenge yet to be solved at the New Forest National Park is how to get in touch with the airbnb hosts of the local area a stakeholder group much more difficult to reach. 
National park partner programme turned bad publicity into endorsement

\section{BAVARIAN FOREST NATIONAL PARK}

The Bavarian Forest National Park in Germany has a national park partner programme for hotels, restaurants and bus and train companies. Every business operator in the local area that comes into contact with potential national park visitors can join if they meet certain criteria such as supporting national park values, offering information about the national park and so on. The staff includes a part-time employee working solely with the national park partners, keeping them informed, preparing seminars, etc.

In the 1990's, the national park learned that some of the local hotel owners had very little sympathy and understanding for the national park and did not inform their guests properly about e.g. the bark beetle calamity that turned the forest into grey, dead trees in these years. The partner programme was an answer to the bad publicity - the bark beetles being long gone. Today, the park has 65 partner hotels endorsing the park.

The national park partners are required to inform their guests about the park. In return, the partners can brand themselves with the certificate of 'National Park Partner'. To become a hotel partner, the hotels have to get an ecology label from the State of Bavaria and at least a three-star rating from the German Hotel Association.

\section{Education programme for stakeholders in a nationwide park project}

\section{THY NATIONAL PARK}

Thy National Park in Denmark is in the process of developing a specific skills development project called The National Park School. The project is supported by The Outdoor Council and focuses on teaching communication and good hosting to a number of stakeholders:

$\rightarrow$ National Park Friends, e.g. summer house owners and local citizens

$\rightarrow$ Front of house staff in tourism and retail

$\rightarrow$ Volunteer national park hosts

$\rightarrow$ National park tour guides, private as well as volunteers

$\rightarrow$ School teachers

The project is carried out in close cooperation with the other national parks in Denmark. Together, the parks have made a common strategy for how to implement the project a strategy to be revised at the end of the project, with Thy National Park serving as the 'test area' for the project. The involved parks hold regular Skype meetings where they discuss the project. In this way, they secure a broad ownership among the stakeholders, which will make use of and implement project results. The national park has also made a handbook about good hosting for the front of house staff in and around the park. The purpose of the handbook is to prepare them for answering questions from the guests and providing knowledge about park values, appropriate behaviour in nature, etc.

Thy National Park, Denmark.

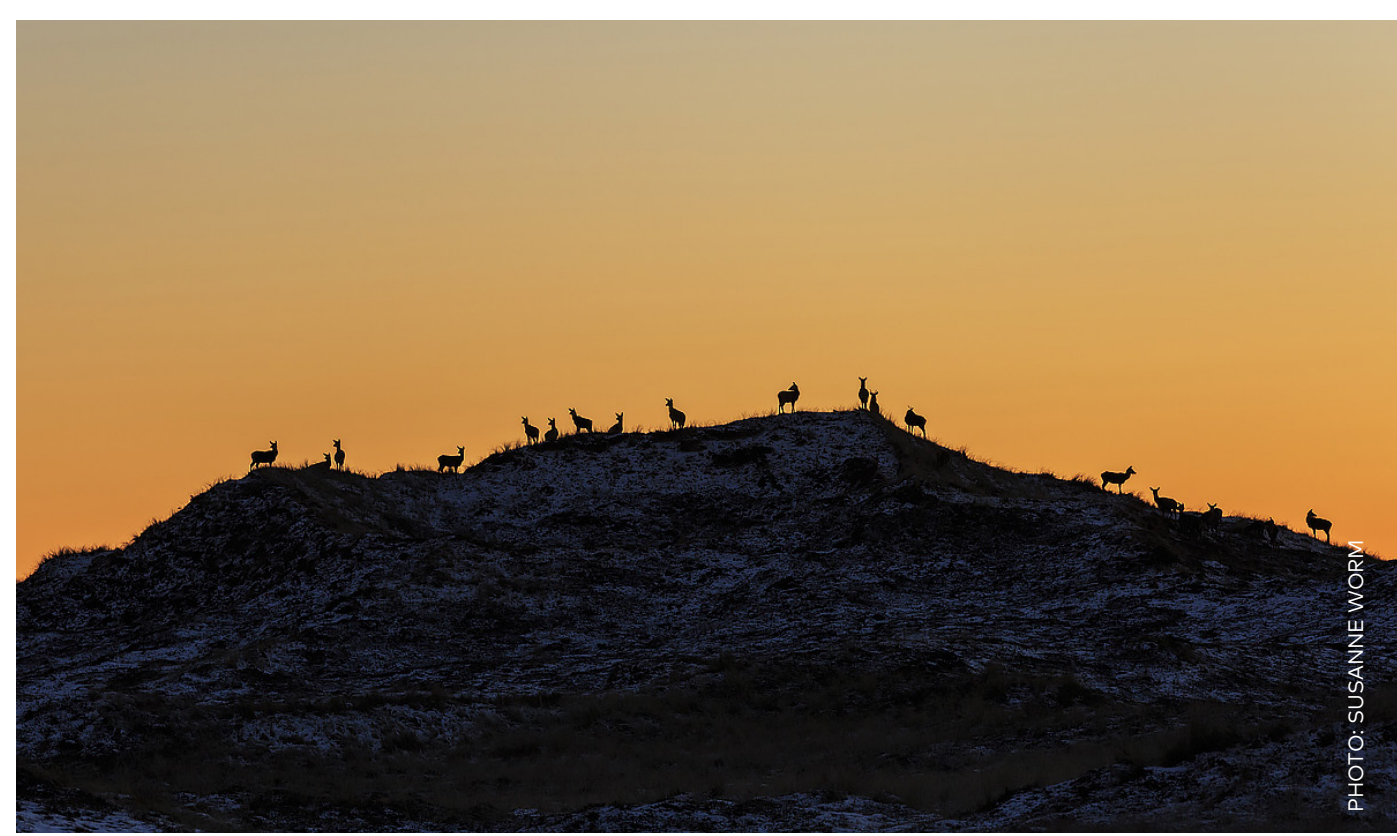


Partnerships with local tourism businesses strengthen sustainable tourism SEVEN NATIONAL PARKS IN EASTERN FINLAND

More and more visitors in Finnish national parks are willing to pay for the services offered by local tourism businesses, such as guided tours, equipment rental and accommodation. This has created a need for the parks to ensure that these businesses comply with the rules and values of the parks. Seven national parks in Eastern Finland that share a common administration have created a partnership agreement scheme to address this need. The parks are: Repovesi, Kolovesi, Petkeljärvi, Patvinsuo, Tiilikkajärvi, Koli and Linnansaari.

The partnership agreement is optional, but the park administration strongly advises all businesses operating in or near the parks to opt in. Besides following park rules and paying a small fee for using the park facilities, the core of the agreement is that the businesses themselves commit to following six principles of sustainable tourism. The businesses in the partnership range from small tour guide businesses of 1-2 people to large hotel chains.

Today, the seven parks have concluded a total of 110 partnership agreements. Every year, the parks host meetings or seminars for the business partners at each major destination (usually three separate meetings). This is an opportunity to inform about new initiatives at the parks, listen to concerns and share feedback and ideas. Partnership businesses will also be invited to participate in the development of e.g. a new management plan. The close involvement of local businesses has created a shared understanding of how to balance the use and the protection of the parks.

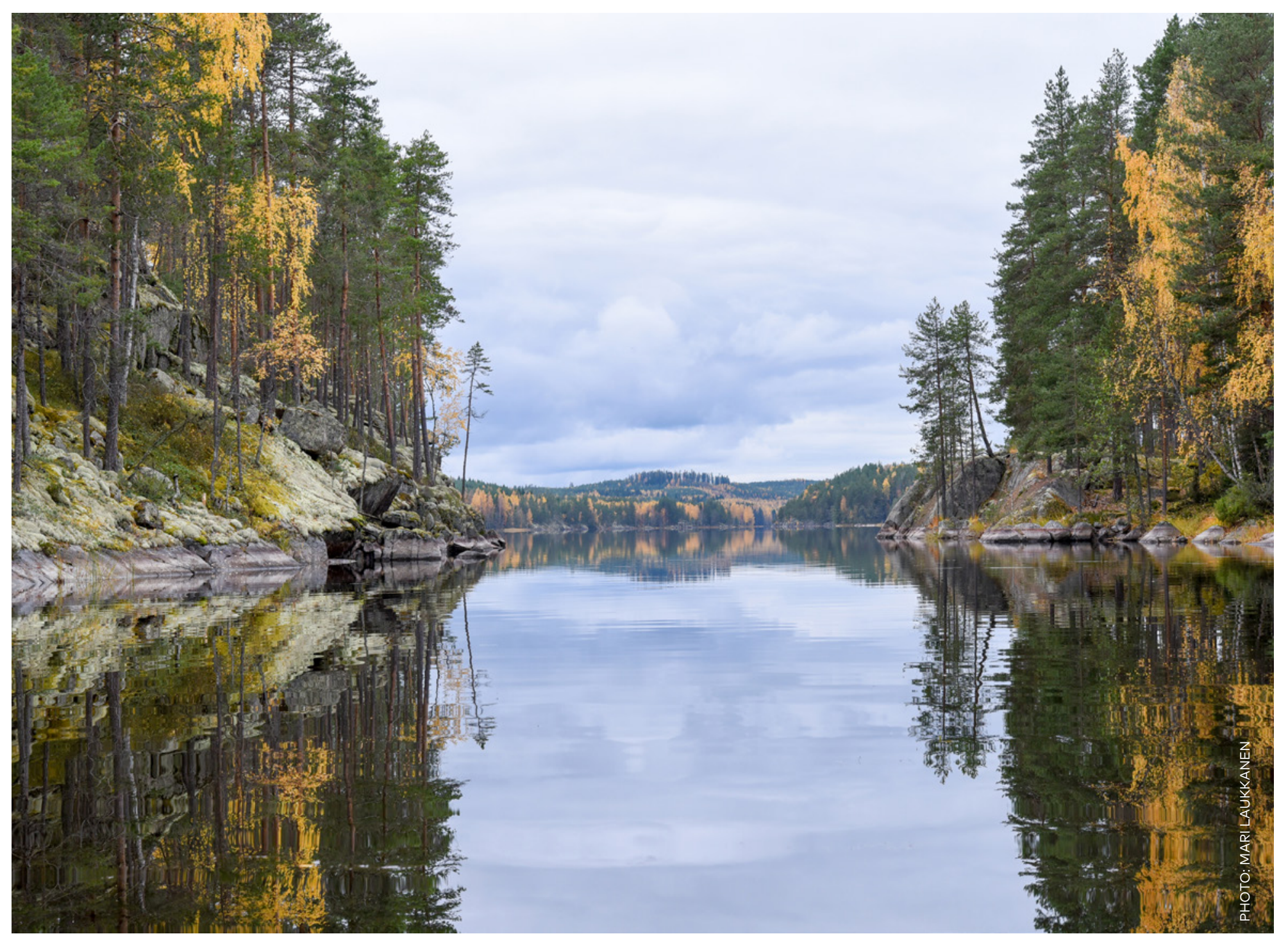

Kolovesi National Park, Finland 
Partnership programmes at

\section{MOLS BJERGE NATIONAL PARK}

Mols Bjerge National Park in Denmark has created the National Park Service Network and Service Education. The goal is to expand the park's network, strengthen the cooperation between local businesses and educate them on how to become good national park hosts.

To become a part of the network it is compulsory to attend a free three-day course about the park, its nature and attractions and what it means to be a good host. Secondly, attending the three annual meetings in the National Park Network is required.

The themes of the meetings vary from preparing high season initiatives to inviting guest speakers on topics requested by the network. According to the park administration, the programme has been a success. Currently, the network has 62 business members, and more than a hundred people from local businesses have participated in the three-day course that now has a waiting list.
The network of businesses will be taking an active part in informing visitors in the area about the national park and its code of conduct, once it is done. And the programme has already resulted in many different new initiatives and collaborations among the network partners.

Ebeltoft Vig, Mols Bjerge National Park Denmark.

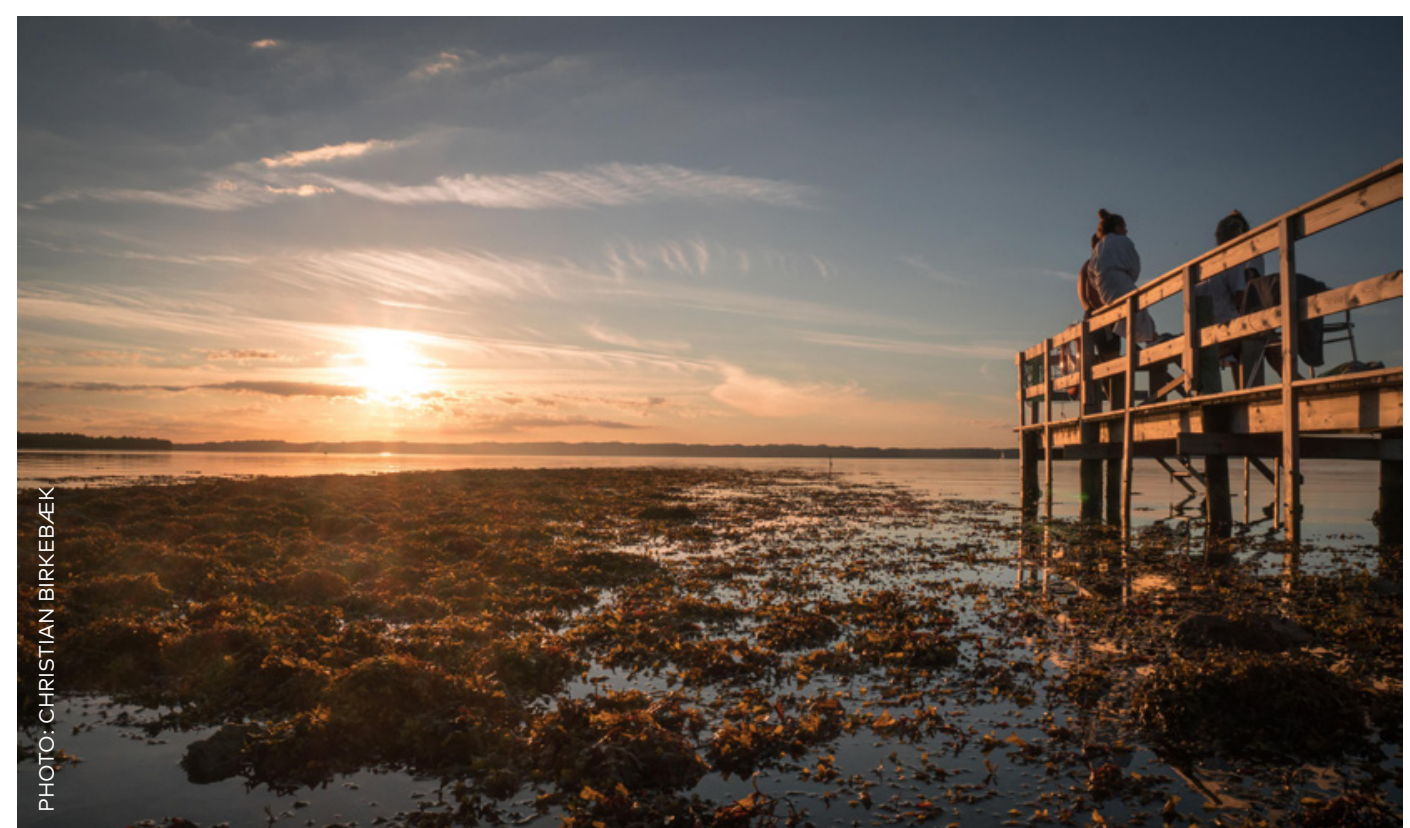

The National Park Partnership Plan ensures commitment among stakeholders

\section{CAIRNGORMS NATIONAL PARK}

In Cairngorms National Park in Great Britain, the National Park Partnership Plan is the overarching management plan for the park. It sets out how all actors with a responsibility for the park will co-ordinate their work to tackle the most important issues over the next five years. The level of involvement of the stakeholders in shaping the management plan varies from time to time. One year, $£ 25,000$ were distributed to 20 different communities, which were given the freedom to decide how to consult with their community. Each area did it differently. In one area, the mothers were involved, in another one post boxes were put up for people's suggestions. In one area, phone calls were made to all the local inhabitants, and in yet another area, farmers and landowners were persuaded to getting involved by means of a chat and a bottle of whisky. In other words, many creative involvement methods were tried out. However, it did prove difficult to extract an actual plan from this. Last time, a more traditional set-up with community meetings and stakeholder workshops was chosen. 
A unique collaboration between the Danish Nature Agency and vollenteer mountain bike trail builders THE DANISH STATE FORESTS

A single, official mountain bike trail in Denmark back in 2000 has multiplied into 200 trails in 2018. This has happened through the project 'On Trail', an ambitious collaboration between the Danish Nature Agency, DGI (Danish Gymnastics and Sports Associations) and volunteer mountain bike trail builders. It all began when a local mountain bike group from Copenhagen approached the Danish Nature Agency. Since then, the project has grown, and today, more than 1,000 volunteers have contributed to the building of mountain bike trails in the Danish state forests, creating the biggest volunteer success story in the history of the Danish Nature Agency.

Sometimes so-called 'pirate trails' (illegal loops) appear on the Danish mountain bike trails, despite the successful collaboration,. The volunteers are very vigilant and take great responsibility in combating this phenomenon internally. They will quickly make aware of such trails and stress in the Facebook group that this is not acceptable.

Some of the built trails pass through national parks. Skjoldungernes Land National Park features two trails, which were built before the national park was established. There are also trails at Thy National Park and The North Zealand of the Kings National Park.
In some places, the local division of the Danish Nature Agency make materials available for the trail builders, and in

other places, the municipality contributes to the purchase of materials. And every year, Spor- og Naturudvalget - a trail and nature committee that works to promote a sustainable mountain bike culture - organises a trail builder conference for the Danish Nature Agency and volunteer trail builders, where knowledge and experiences are exchanged.
The 'On Trail' project strongly emphasises the need for the built trails to be sustainable; the trails must allow easy repair and maintenance, cannot pass through fragile natural and cultural values in the landscape and must be marked and designed to minimise conflicts with other users. Spor- og Naturudvalget is working on disseminating the principles for proper mountain bike trails to all associations and selforganised groups. Nordea-fonden has donated 10.7 million Danish kroner to the 'On Trail' project.

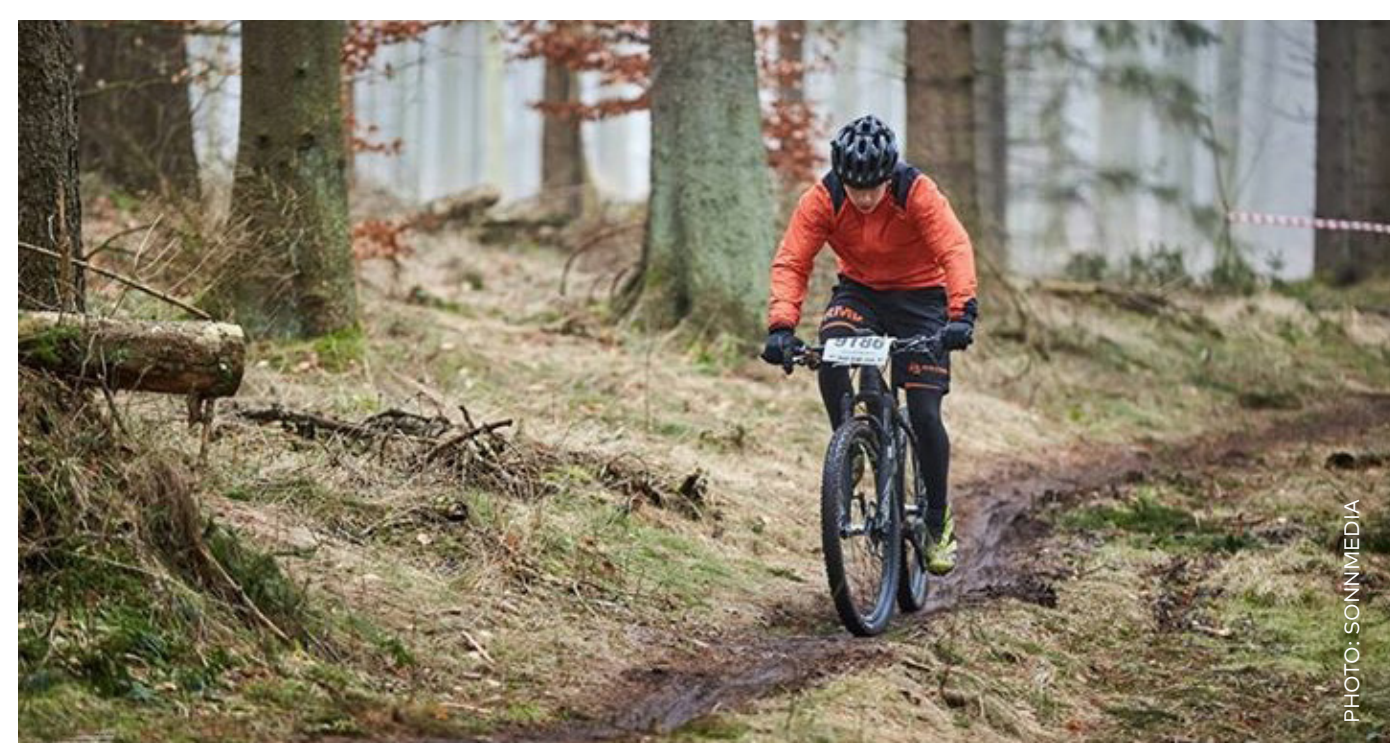




\section{Monitoring}

Monitoring in itself is not a visitor management solution, but rather a systematic collection of data on the condition and development of nature, visitor behaviour, traffic, local attitudes, etc., which brings forward new or updated knowledge about ecological, social and economic factors. Monitoring is a tool that helps lay the foundation for developing tailored, efficient and sustainable visitor management solutions. As seen in one of the examples, monitoring data is not only of intrinsic value to the management of the national park but can also be used as a way of directing political attention to the value added to the local community by the national park.

Weerribben-Wieden National Park the Netherlands. 


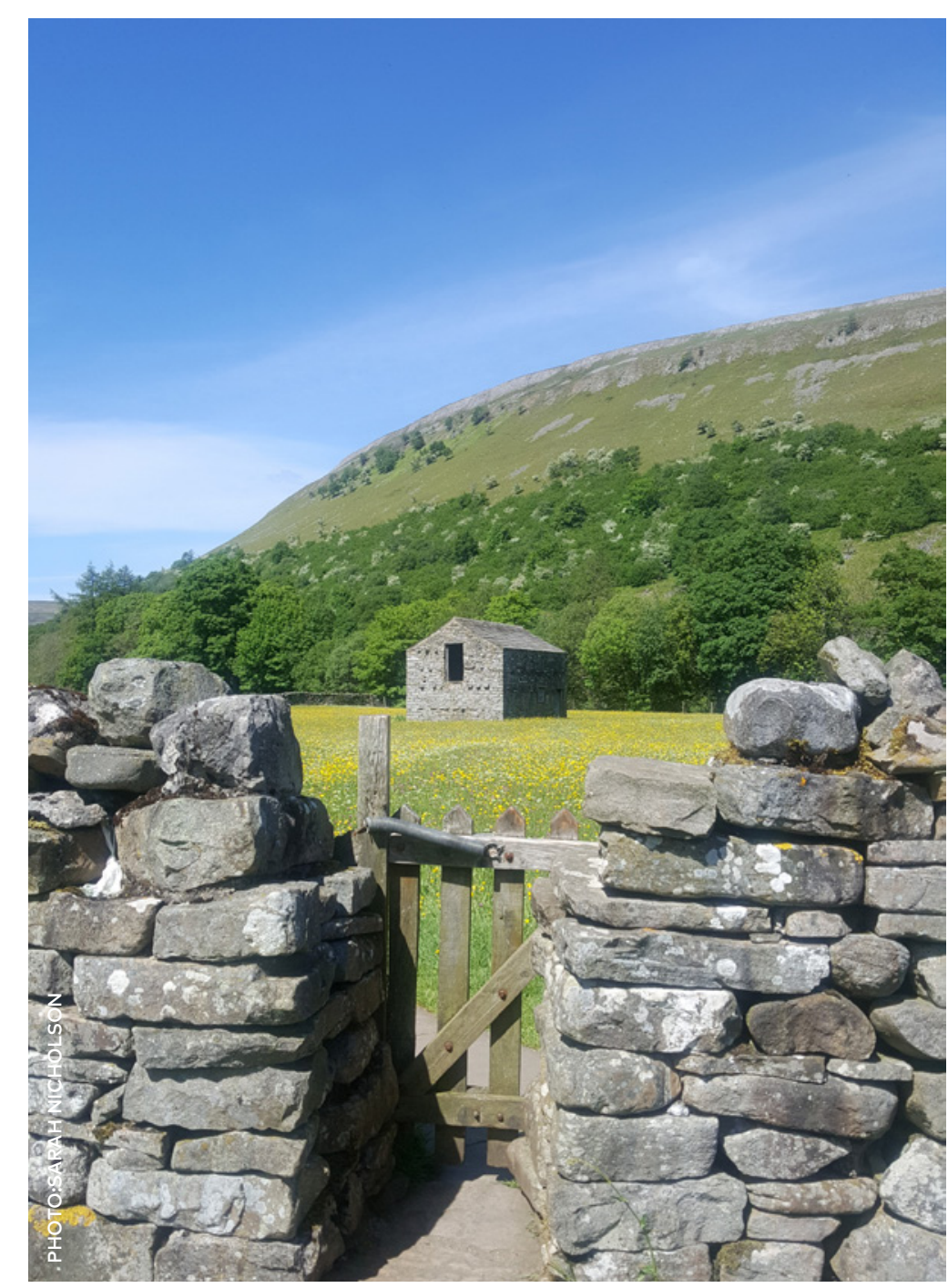

Monitoring trends in visitors and their expenditure YORKSHIRE DALES NATIONAL PARK

Yorkshire Dales National Park in Great Britain is taking an active part in supporting the local environment. In order to measure the economic impact, the park uses the internationally recognised monitoring model STEAM (Scarborough Tourism Economic Activity Monitor). This model collects data on visitor attraction numbers, tourist accommodation, occupancy levels, accommodation tariffs, macro-economic factors, visitor expenditure levels, transport use levels and more.

The information is gathered from businesses, visitor centres, car parks, etc. The trends are monitored in two ways: Reports for the national park (2016 saw 3.7 million visitors) and for what has been defined as the area of influence (2016 saw 9 million visitors). The area of influence has been defined because many of the services used by visitors are actually situated outside the national park.

The output of the STEAM model can be used to show the economic impact of visitors and monitor visitor trends. The figures are not absolute, but the STEAM model provides useful trend data and is used by the majority of the national parks in Great Britain

Yorkshire Dales National Park,

Great Britain.
The STEAM (Scarborough Tourism Economic Activity Monitor)

STEAM is a tourism economic impact modelling process which approaches the measurement of tourism from the bottom up. The STEAM process is essentially a structured framework with the capacity to accept a wide range of tourism input data.

STEAM quantifies the local economic impact of tourism from both staying and day visitors, through analysis and use of a variety of inputs including visitor attraction numbers, tourist accommodation bedstock, events attendance, occupancy levels, accommodation tariffs, macro-economic factors, visitor expenditure levels, transport use levels and tourism-specific economic multipliers.

Read more:

www.globaltourismsolutions.co.uk/steam-model 


\section{Creating political incitement through visitor surveys REPOVESI NATIONAL PARK}

Repovesi National Park in Finland is facing increasing visitor numbers and has had many problems with over-crowding. Every five years, the park administration conducts a visitor survey where data on the visitors' experiences and satisfaction, activity patterns, money expenditure in the park, etc. is collected.

Through the visitor survey, the park gathers information about the condition of trails and other facilities in the parks, as well as information about visitor needs and wishes when it comes to over-crowding issues, signage, trail connections, service facilities, etc. The information flows into development plans for Repovesi National Park, which describe a range of specific projects, some of which are financed through extra funding from e.g. national or EU funding programmes.

The visitor survey results can also be used as an argument for continued or increased funding in the long term. Based on the data, the park administration can show the park's economic impact on the local and regional community and thus build a political argument for funding that can help protect and develop the national parks.

\section{Handbook for assessing \\ vulnerability in}

\section{NORWEGIAN NATIONAL PARKS}

In Norway, the Norwegian Institute for Nature Research (NINA) is in the process of developing a handbook for Norwegian national parks on the mainland for mountain, forest and coastal areas, similar to the handbook they developed for Svalbard mentioned on page 28. The purpose of the handbook is to assist national park managers in measuring and assessing the vulnerability of vegetation and animal life.

The point is not to make a general vulnerability assessment of the whole national park, but rather to single out the areas with human traffic, focusing on the particular sensitivity of the nature and landscape in that specific locality. Vulnerability is a phenomenon that occurs in the interaction between a sensitive environment and humans, meaning that the degree of an area's vulnerability is determined as a function of its sensitivity and its human traffic/visitor behaviour.

The handbook is designed to be used by national park managers as a rather simple tool to help them develop site-specific guidelines based on vulnerability assessments. It also features examples of concrete visitor management solutions, showing how protection and visitor experience and service can be united in the same solution. An example could be a wooden boardwalk ${ }^{16}$ in sensitive marsh areas that protects nature and also provides easy and comfortable access. The handbook will be finished in 2019

${ }^{16}$ According to the definition of this publication, a boardwalk is a hard management tool. Such tools are increasingly accepted in Nonwegian national parks, despite the strict regulations concerning the building of new structures in the parks. New trends such as the increase in bicycle tourism, which has caused a significant erosion of paths in many areas, has however softened regulations and has allowed for - among other things - the use of path reinforcement initiatives as a part of the visitor management toolbox. Accepting that even some hard management tools are very efficient when it comes to maintaining certain natural resource qualities and the attractivity of the area seems to be a general trend in Norwegian outdoor life and management culture. 

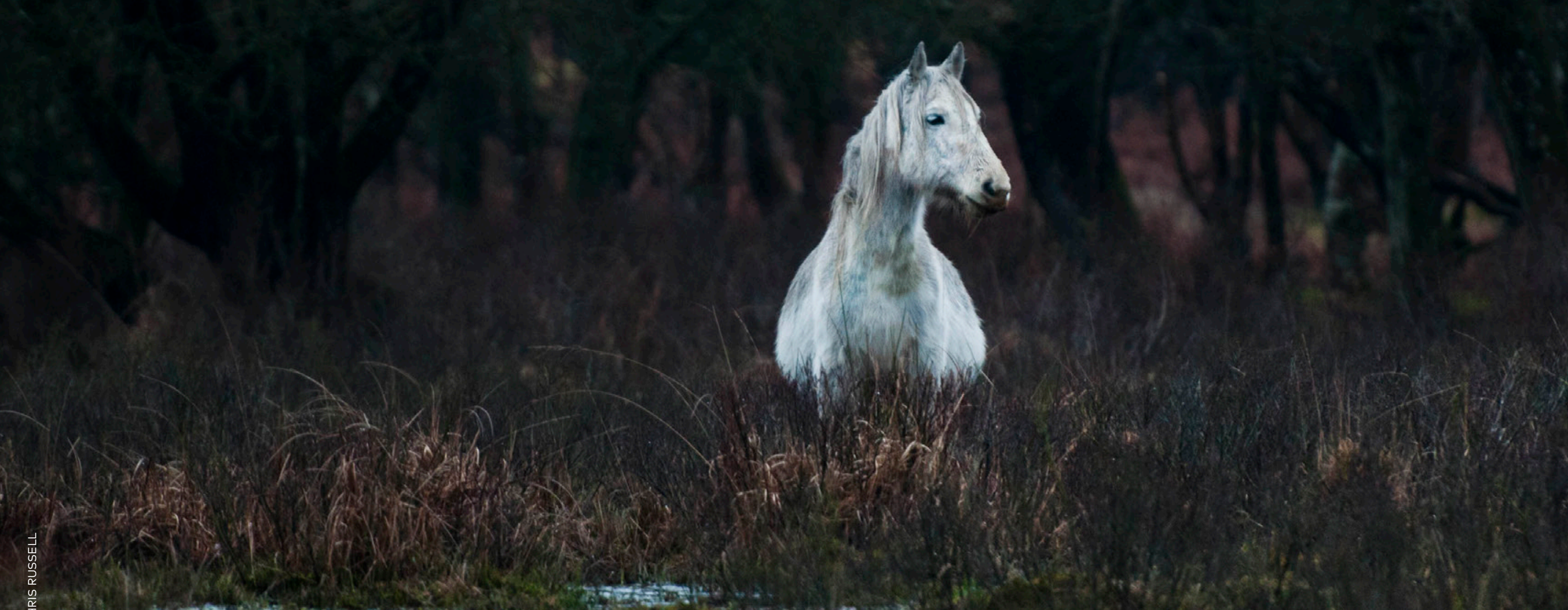

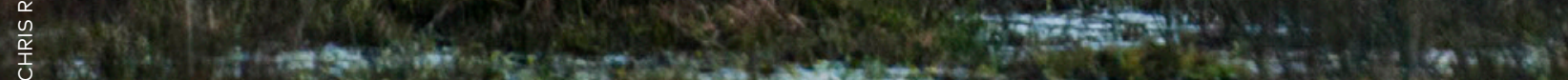
: 00 .

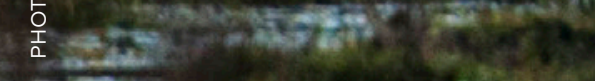

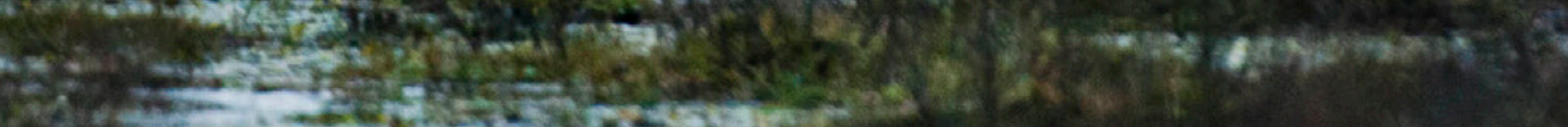




\section{Method}

This publication is based on interviews with managers and employees in 14 national parks (nine in the Nordic countries and five in othe European countries) and on interviews with range of researchers and experts in the field of nature preservation, cultural heritage and tourism as well as government agency officials from the five Nordic countries, many of them members of the reference group on this project.

In April 2018, a workshop was held in Iceland with the participation of the three partnership parks (Jotunheimen National Park in Norway, The Wadden Sea National Park in Denmar and Thingvellir National Park in Iceland) and members of the project's reference group.

The publication is also based on extensive desk research on publications and research reports, with a special focus on the report 'Tourism, nature and sustainability' published by the Nor- dic Council of Ministers in 2018 ${ }^{17}$. The report is a review of policy instruments in the Nordic countries and deals with the issues of visitor management. It discusses the challenges that arise due to the rapid increase in visitors to Nordic nature attractions and destinations, and gives recommendations on how to apply a set of policy instruments in an environmental$y$, socially and economically sustainable way as an answer to these challenges.

The publication builds upon the conclusions and recommendations of this report by presenting more than 30 concrete best practice examples from Nordic and European national parks concerning a variety of visitor management solutions with the aim of inspiring Nordic national parks to develop more sustainable visitor management solutions.

Authors of the report are Hogne Øian, Peter Fredman Klas Sandell, Anna Dóra Sæpórsdóttir, Liisa Tyrväine and Frank Søndergaard Jensen. 

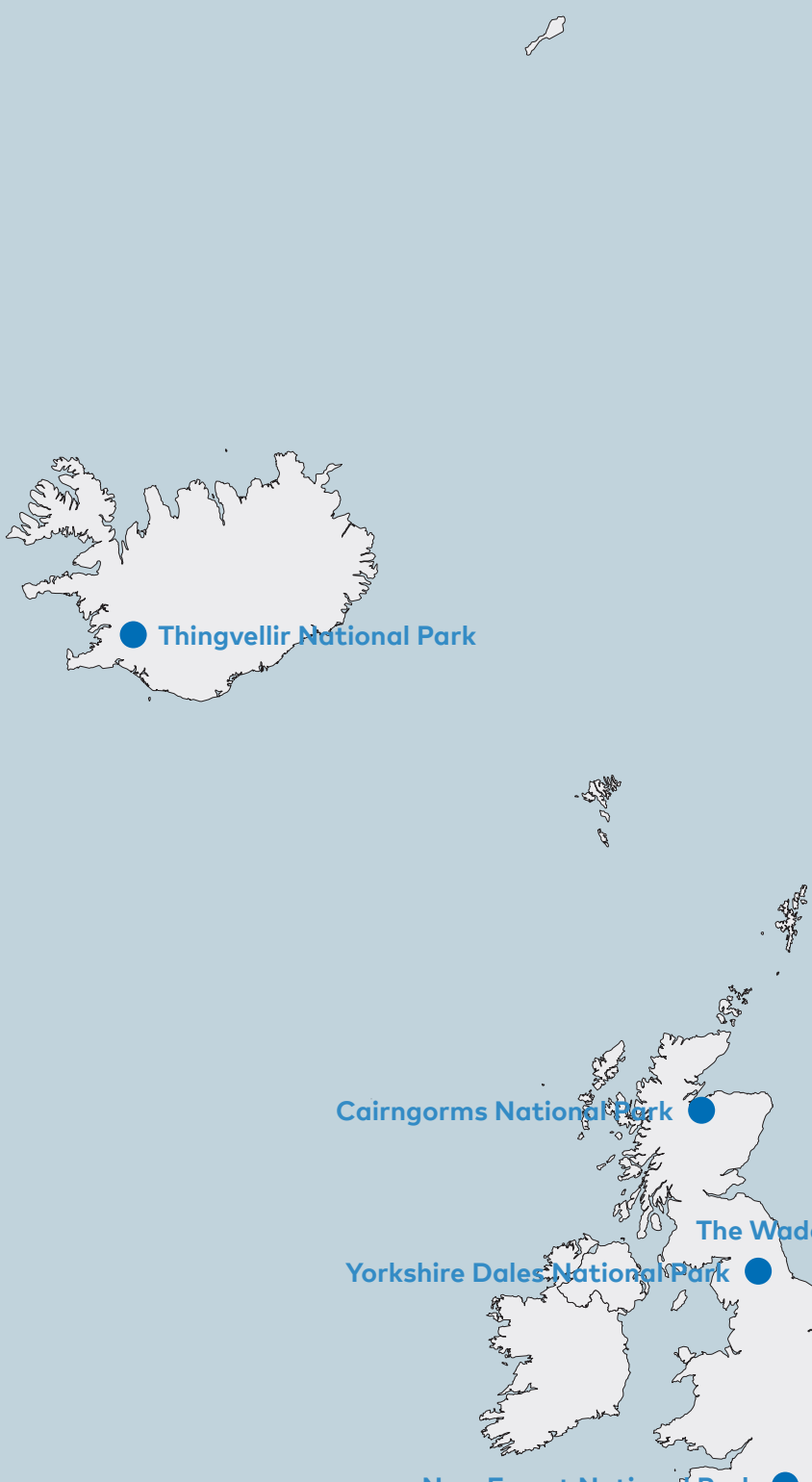

New Forest Nationgil Park

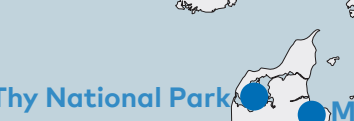

Thy National Park

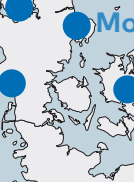

Weerribben--Wieden National Park
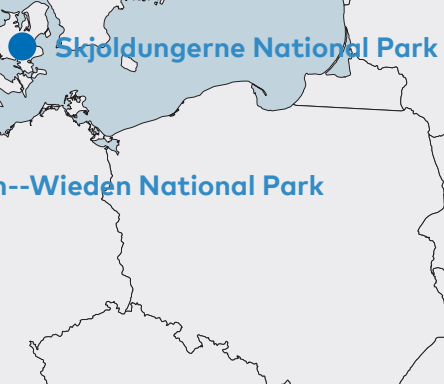


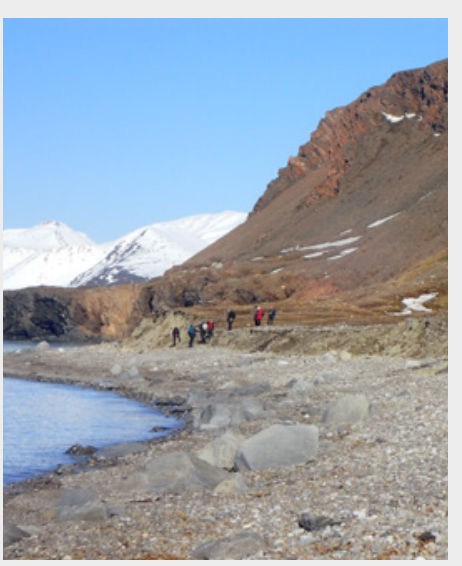

SVALBARD

Svaldbard is an archipelago in the Arctic Ocean. It has seven national parks and 21 nature reserves that cover two thirds of the islands. Apart from a few human settlements, the land is desolate and wild. Approximately 60 percent of the archipelago is covered by glaciers, and the landscapes of the islands are characterised by mountains and fiords.

$\rightarrow$ Location: Svalbard, Norway

$\rightarrow$ Parks established in 1973, 2003 and 2005

$\rightarrow 67,400$ visitors in Svalbard per year

$\rightarrow$ The typical visitors are cruise ship guests, experienced hikers and staying visitors that go on boat tours and ride dog sleds and snowmobiles.

$\rightarrow$ Size: The 7 national parks cover $34,300 \mathrm{~km}^{2}$

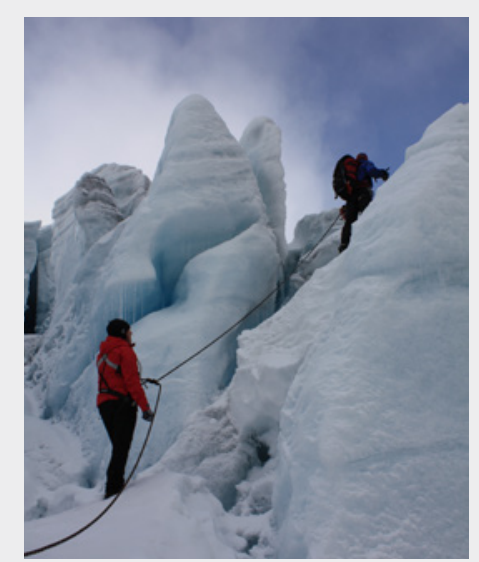

\section{JOTUNHEIMEN NATIONAL PARK}

Jotunheimen National Park has the highest mountains in Northern Europe with over 250 mountains taller than 2,000 metres. The park landscape also features lakes, glaciers and a range of cultural sites, as well as a diverse wildlife with reindeer, elk, deer, weasel, wolverine, lyn trout, golden eagle, grouse and gyrfalcon.

$\rightarrow$ Location: Oppland County and Sogn and Fjordane County, Norway

$\rightarrow$ Established in 1980

$\rightarrow 250,000-300,000$ visitors per year

$\rightarrow$ The typical visitors are day or weekend visitors, about half of them from Norway. Visitors mainly come to to hike, or to ski in the winter. Other typical activities are mountain climbing and glacier walking. Mountain biking is a growing activity in the areas around the park.

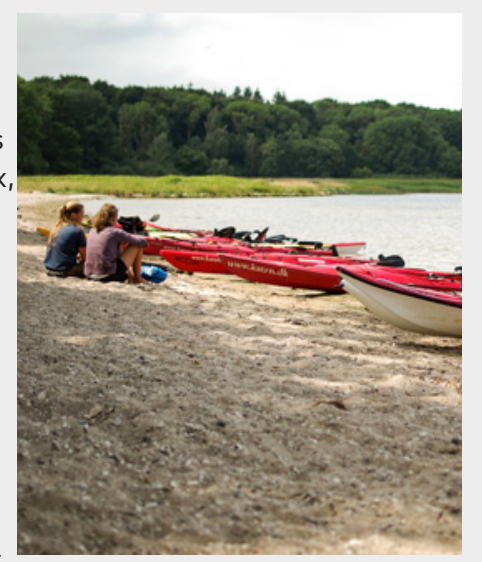
National Park Skjoldungernes Land surrounds Roskilde Fiord. The landscape is characterised by forest, hills and a $100 \mathrm{~km}$ coastline. It also features historical monuments and cultivated land. The area of the park has about 9,000 residents.

$\rightarrow$ Location: Roskilde, Denmark

$\rightarrow$ Established in 2015

$\rightarrow$ In 2015, 600,000 people visited the main attractions at the national park. The number of nature visitors is unknown.

$\rightarrow$ The typical visitors are day visitors, locals and water sports enthusiasts.

$\rightarrow$ Size: $1,151 \mathrm{~km}^{2}$ $\rightarrow$ Size: $170 \mathrm{~km}^{2}$ 


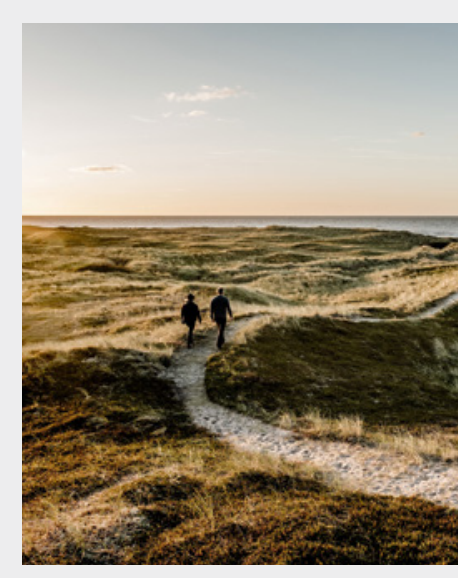

THY NATIONAL PARK

Thy National Park is a desolate wilderness by the western coast of Jutland. The landscape is characterised by dunes, dune plantations and heathlands and has a rich bird-and wildlife and a large population of red deer.

$\rightarrow$ Location: Thy in Jutland, Denmark

$\rightarrow$ Established in 2008

$\rightarrow$ 1.2-1.5 million visitors per year

$\rightarrow$ The typical visitors are people, including local residents, with a particular interest in nature. Visitors come for hiking, bicycling and for an authentic wilderness experience.

$\rightarrow$ Size: $244 \mathrm{~km}^{2}$

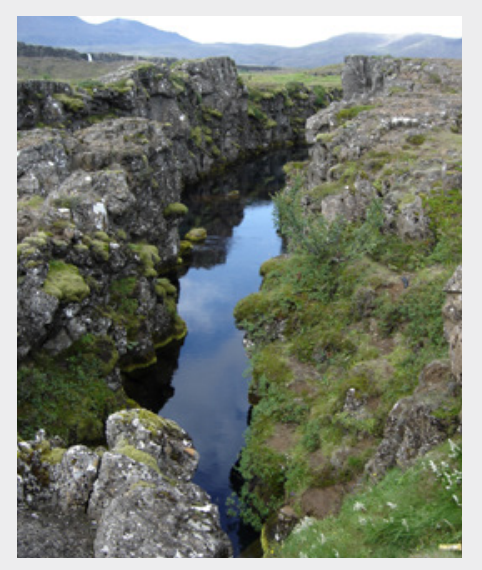

THINGVELLIR NATIONAL PARK

Thingvellir National Park has a unique geological landscape with mountains, a waterfall and crystal-clear glacial water. The Thingvellir area is a part of a fissure swarm running

through Iceland due to the island's location on the tectonic plate boundaries of the Mid-Atlantic Ridge. Iceland's his-

toric democratic parliament was founded here in 930 AD.

$\rightarrow$ Location: Thingvellir, Iceland

$\rightarrow$ Established in 1930

$\rightarrow 1.2$ million visitors in 2016

$\rightarrow$ The typical visitors are foreign tourists on day trips

$\rightarrow$ Size: $228 \mathrm{~km}^{2}$

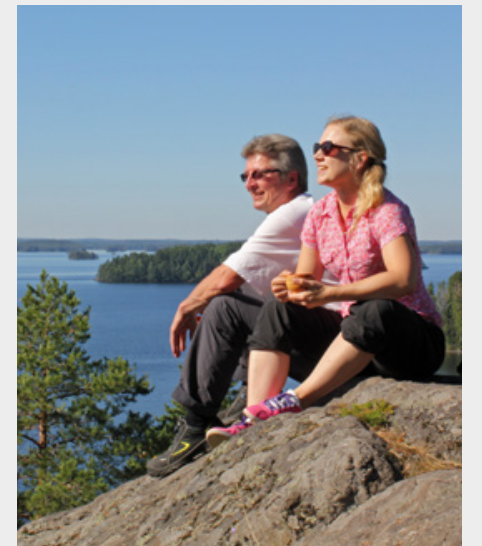

REPOVESI NATIONAL PARK

Repovesi National Park is a rugged pine and birch forest

Mols Bjerge National Park is a populated natural area characterised by its ice age landscape with glacial plains and kettles, including a castle ruin from the Middle Ages.

$\rightarrow$ Location: Rønde, Denmark

$\rightarrow$ Established in 2009

$\rightarrow 2.3$ million visitors per year

$\rightarrow$ The typical visitors are holidaymakers and local day visitors

$\rightarrow$ Size: $180 \mathrm{~km}^{2}$ dotted with cliffs, lakes and ponds.

$\rightarrow$ Location: Kouvola, Finland

$\rightarrow$ Established in 2003

$\rightarrow 172,000$ visitors in 2017

$\rightarrow$ The typical visitors are day hikers and climbers

$\rightarrow$ Size: $15 \mathrm{~km}^{2}$ 


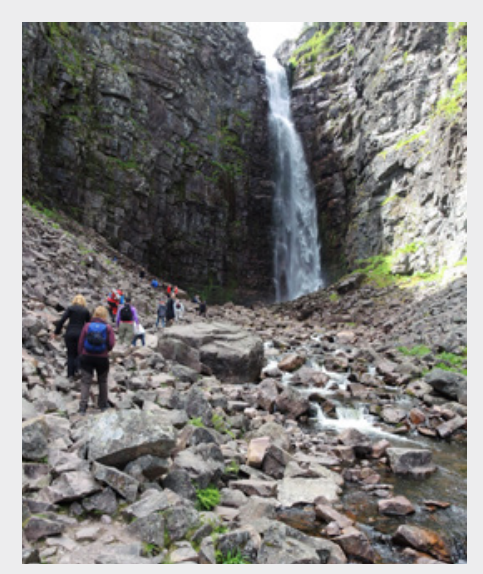

FULUFJÄLLET NATIONAL PARK

Fulufjället National Park is situated on the high plateau of Fulufjället Mountain. The landscape consists of bare slopes, rivers, valleys and old-growth forest.

$\rightarrow$ Location: Älvdalen Dalarna, Sweden

$\rightarrow$ Established in 2002

$\rightarrow 80,000$ visitors per year

$\rightarrow$ The typical visitors are day visiting hikers, campers in tents, bird watchers and anglers

$\rightarrow$ Size: 385 km

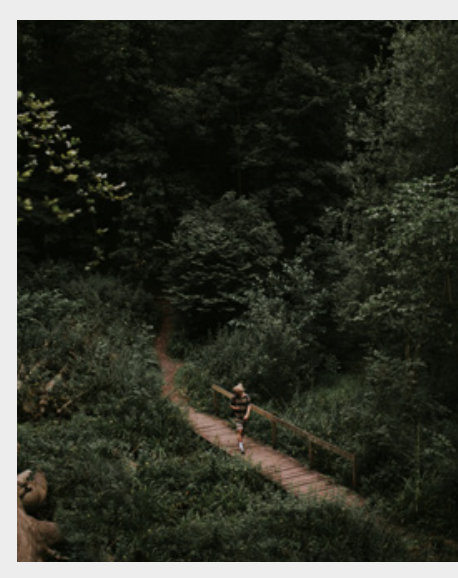

THE NEW FOREST NATIONAL PARK

The New Forest National Park has a variety of landscapes: farmland, ancient woodland, heaths, rivers and valleys and a coastline of mudflats and saltmarshes. 30,000 people

live within the park.

$\rightarrow$ Location: Hampshire, Great Britain

$\rightarrow$ Established in 2005

$\rightarrow$ Between 13 and 15 million day visits per year

$\rightarrow$ The typical visitors are local residents and people from nearby areas. Popular activities include dog walking, walking, cycling, sightseeing, wildlife watching and sailing

$\rightarrow$ Size: $566 \mathrm{~km}^{2}$

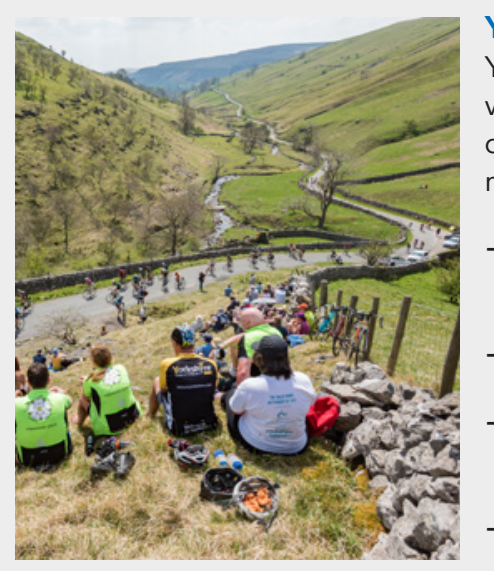

YORKSHIRE DALES NATIONAL PARK

Yorkshire Dales National Park is a limestone landscape

with stone-built villages, traditional farming landscapes,

ancient forests and remains of former mines and other

rural industries. 23,637 residents live and work in the park.

$\rightarrow$ Location: North Yorkshire, Cumbria and Lancashire Great Britain

Britain

$\rightarrow$ Established in 2003

$\rightarrow 1.8$ million visitors per year

$\rightarrow$ The typical visitors are winter sports enthusiasts, locals and day visiting hikers

$\rightarrow$ Size: $4,528 \mathrm{~km}^{2}$

$\rightarrow$ Established in 1954

$\rightarrow$ In 2017, the national park received a total of 3.85 million visitors

$\rightarrow 3.3$ million day visitors and 520,000 overnight visitors.

$\rightarrow$ The typical visitors are day visitors with an interest in walking, sightseeing, visiting pubs and tearooms. The national park also attracts large numbers of cyclists.

$\rightarrow$ Size: $2,179 \mathrm{~km}^{2}$ 

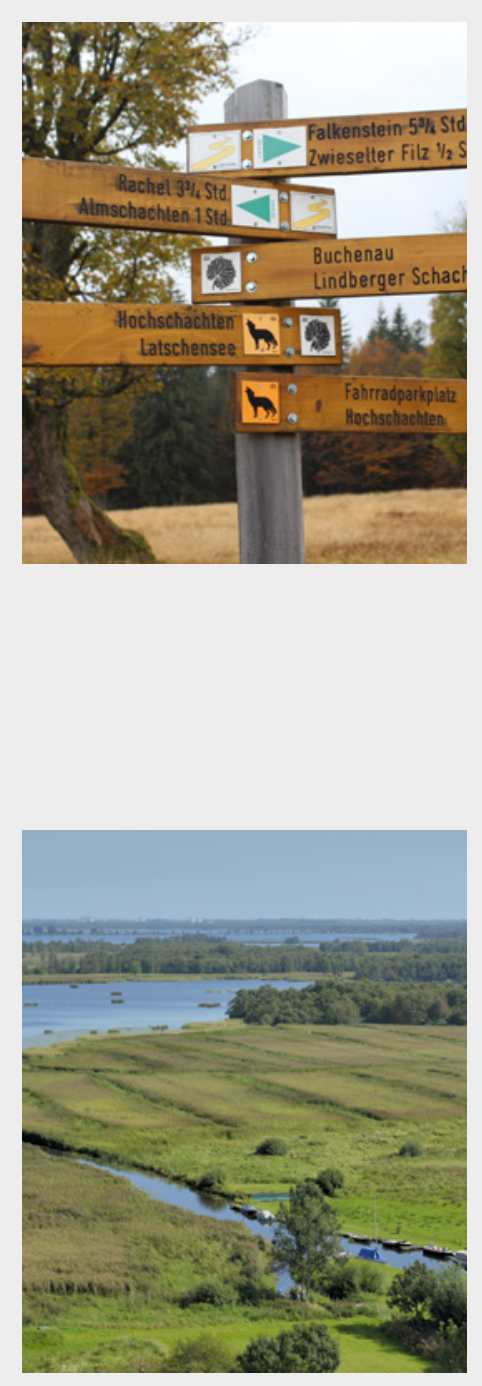

Visitor management in nordic national parks
THE BAVARIAN FOREST NATIONAL PARK

The Bavarian Forest National Park is a wooded, low-moun-

tain land that runs along the main ridge of the Bavarian

Forest and is inhabited by lynx, wolf, deer and capercaillies.

$\rightarrow$ Location: Bavaria, Germany

$\rightarrow$ Established in 1970

$\rightarrow 1.3$ million visitors per year

$\rightarrow$ The typical visitors are families and couples interested in hiking and nature experiences.

$\rightarrow$ Size: $243 \mathrm{~km}^{2}$

\section{WEERRIBBEN-WIEDEN NATIONAL PARK}

Weerribben-Wieden National Park is a freshwater marsh-

land landscape characterised by lakes, ponds, canals,

peatlands, reed beds and forests. The national park also

features a number of small villages, which used to be only accessible by water.

$\rightarrow$ Location: Steenwijkerland, The Netherlands

$\rightarrow$ Established in 1986

$\rightarrow 2.7$ million visits per year

$\rightarrow$ The typical visitors are foreign tourists and regional residents, often travelling in boats and kayaks (they do not travel to the national park by boat or canoe, but these means are a great way to explore the place)

$\rightarrow$ Size: $100 \mathrm{~km}^{2}$ 


\section{$\mathbb{1}$}

Nordic Council of Ministers

Nordens Hus

Ved Stranden 18

DK-1061 Copenhagen

www.norden.org

Visitor management is a key tool in improving the recreational carrying capacity of the Nordic national parks, in light of the challenges presented by growing visitor numbers and new types of visitor behaviour. A more strategic and collaborative approach to visitor management can help protect and develop national parks and their local communities in both an environmentally, socially and economically sustainable way.

This publication offers Nordic national park managers and national park authorities inspiration on how to improve their visitor management. It contains a collection of examples of what other national parks, within as well as outside of the Nordic countries, have done to improve their visitor management and suggests overall recommendations on how to create better visitor management within a Nordic framework.

The publication is the result of a project supported by The Nordic Council of Ministers' Terrestrial Ecosystem Group (TEG) and carried out in a partnership consisting of Thingvellir National Park in Iceland, Jotunheimen National Park in Norway and The Wadden Sea National Park in

Denmark, with BARK Rådgivning as project manager. 